OSTROM WORKSHOP

PROGRAM ON CYBERSECURITY

AND INTERNET GOVERNANCE

\title{
The Firm as Common Pool Resource: Unpacking the Rise of Benefit Corporations
}

\author{
Janine Hiller \\ Scott Shackelford \\ Xiao Ma
}

Copyright (C) 2017 by authors

American Business Law Journal, forthcoming 2017. 


\title{
THE FIRM AS COMMON POOL RESOURCE: UNPACKING THE RISE OF BENEFIT CORPORATIONS
}

\author{
Janine Hiller JD*, Scott J. Shackelford JD, PhD**, \\ Xiao Ma***
}

\section{Table of Contents}

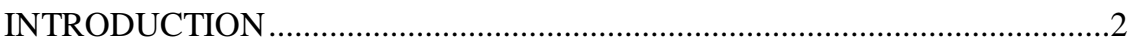

I. POLYCENTRIC GOVERNANCE AND BUILDING SOCIALLY

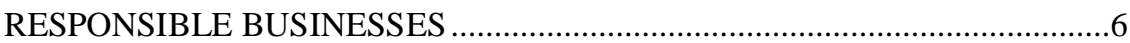

II. CORPORATE VISIONS: SITUATING THE BENEFIT CORPORATION

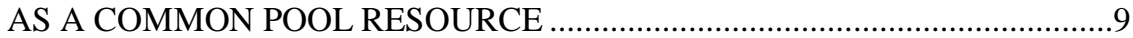

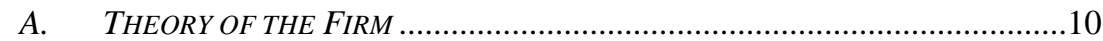

B. LEGAL APPLICATION OF THE THEORY OF THE FIRM ...............................14

C. BENEFIT CORPORATIONS: A NEW (OLD?) CONCEPTION OF THE FIRM .....17

III. CASE STUDIES IN BENEFIT CORPORATION FORMATION .......21

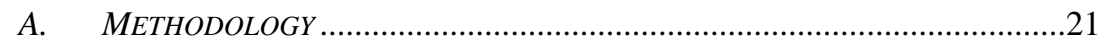

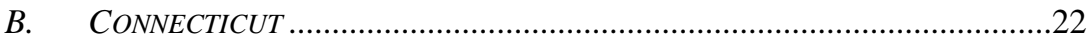

1. The History of the Benefit Corporation Legislation Campaign in

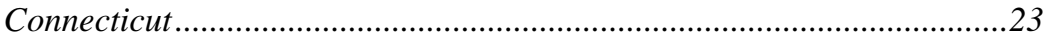

2. Stakeholder Advocacy for the Connecticut Benefit Corporation

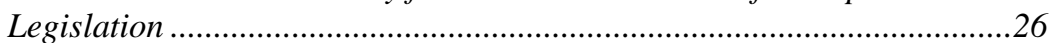

3. Local Impact of Benefit Corporation Legislation .............................28

C. DELAWARE ……..............................................................................

1. The History of Benefit Corporation Legislation Campaign in

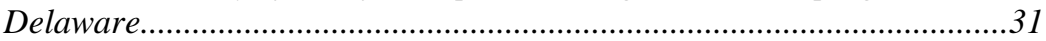

2. Stakeholder Advocacy for Delaware Benefit Corporation

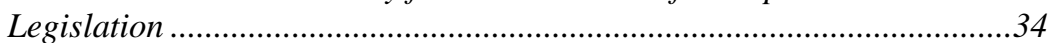

3. Local Impact of Benefit Corporation Legislation .................................36

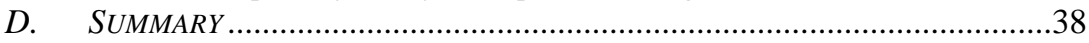

IV. ANALYZING THE RISE OF BENEFIT CORPORATIONS AND

THEIR GLOBAL IMPACT THROUGH POLYCENTRIC GOVERNANCE ..41

A. APPLYING THE OSTROM DESIGN PRINCIPLES TO BENEFIT CORPORATIONS 41

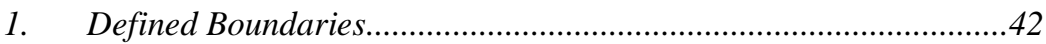

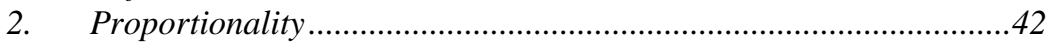

3. Collective-Choice Arrangements and Minimal Recognition of Rights 42

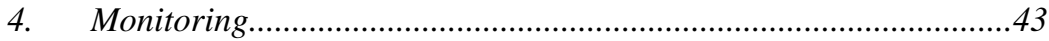

5. Graduated Sanctions and Dispute Resolution ...................................43

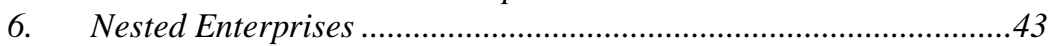

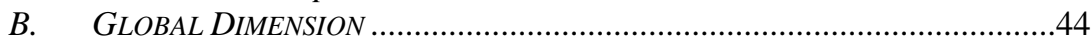

1. Defining "Social Enterprise”" Globally ..........................................45

2. Unpacking European Socially Responsible Corporate Law............45

3. Case Study: The UK's Community Interest Company Approach ....48

C. LOOKING AHEAD AND APPLYING LESSONS LEARNED ...............................50

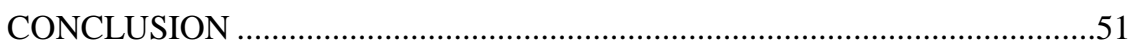




\section{INTRODUCTION}

In September, 2015, the crowd-funding site Kickstarter announced that it was adopting a new corporate form, that of a public benefit corporation, to help "ensure that money - or the promise of it - would not corrupt their company's mission of enabling creative projects to be funded." ${ }^{1}$ Kickstarter is not unique; it joined a growing list of tech firms that are moving towards adopting a benefit corporation designation. Before the benefit corporation statutes were passed by state legislatures, companies like Kickstarter could nonetheless choose to join a voluntary certification known as a "BCorp;" there were nearly three thousands BCorps across the country as of November 2016, such as Ben \& Jerry's, Patagonia, and Seventh Generation. ${ }^{2}$ The voluntary certification is meant to be replaced by a new legal form of business when state statutory options are available, and the movement is strong with thirty-one states having benefit corporation statutes. ${ }^{3}$ The result of the legal movement is that companies across the nation are changing, impacting everything from business ethics training to Board decision-making, with wideranging implications for the economy, environment, and civil society. ${ }^{4}$

Despite its popularity, the rationale behind the emergence of benefit corporations is a perplexing question. Because of constituency statutes and the ability of corporations to modify their articles of incorporation to achieve many benefit corporation principles, it is puzzling why the new form has caught on in state legislatures, including Delaware. ${ }^{5}$ Some scholars argue that there is little offered by benefit corporation legislation that could not otherwise be accomplished by firms within their articles of

\footnotetext{
* Professor of Business Law, Richard E. Sorensen Professor in Finance, Pamplin College of Business, Virginia Tech.

** Associate Professor of Business Law and Ethics, Indiana University Kelley School of Business; Research Fellow, Harvard Kennedy School Belfer Center for Science and International Affairs; Director, Ostrom Workshop Program on Cybersecurity and Internet Governance.

*** JD candidate, Maurer School of Law.

${ }^{1}$ Mike Isaac \& David Gelles, Kickstarter Focuses Its Mission on Altruism Over Profit, N.Y. TIMES (Sept. 20, 2015), http://tinyurl.com/gvdfacq.

${ }^{2}$ Find a Benefit Corp, benefitcorp.net, http://tinyurl.com/gsgnxcs (last visited Oct. 21, 2015). This article focuses on benefit corporations, not BCorps.

${ }^{3}$ See Benefit Corporation, State by State Status of Legislation, http://benefitcorp.net/policymakers/state-by-state-status (last visited Dec. 12, 2016); Jamie Raskin, The Rise of Benefit Corporations, THENATION.COM, http://tinyurl.com/zp75ch7 (last visited Nov. 2, 2015).

${ }^{4}$ See Raskin, supra note 3.

${ }^{5}$ See infra Part III(C).
} 
incorporation. ${ }^{6}$ In this Article, we argue that a way to analyze the benefit corporation movement is through a reexamination of the property conception of a corporation; furthermore, the common pool resource (CPR) theory provides a way to understand the puzzle and the future of benefit corporations. ${ }^{7}$

CPR Theory describes four types of goods, defined by where they lie on the spectrum of two primary characteristics; exclusion and subtractibility. Exclusion refers to the ease with which goods can be protected from use by others. ${ }^{8}$ Subtractability evokes the un-sharable nature of the goods; that is, if one person uses the good it subtracts from the pool of available goods. ${ }^{9}$ If it is easy to exclude others from the use of a good, coupled with a high degree of subtractability, then the type of good is likely to be characterized as private goods that are defined by property law and best regulated by the market. ${ }^{10}$ If both exclusion and subtractability are difficult, then the goods are likely characterized as public goods that are best managed by governments. ${ }^{11}$ The third type of goods, called toll goods, are those that exhibit ease of exclusion but high subtractability. ${ }^{12}$ Lastly, common pool goods are those that have high subtractability and difficulty of exclusion, ${ }^{13}$ such as rivers or fisheries. Decades of research has examined best practices to effectively manage common pool goods, including through the literature on polycentric governance as is discussed in Parts I and IV. Such a task can be difficult, as may be seen by way of a common definition of "resource exploitation," which may be understood as "the temptation to overextract fish, steam, or other resource units from a resource

${ }^{6}$ See, e.g., Joan Heminway, Benefit Corporations: What am I MissingSeriously?, LPB NETWORK (Feb. 23, 2015), http://tinyurl.com/zeqllov.

${ }^{7}$ ELINOR OSTROM, GOVERNING THE COMMONS: THE EVOLUTION OF INSTITUTIONS FOR COLLECTIVE ACTION Xv (1990) (noting that CPR theory helps researchers understand why individuals engage in nested collective action arrangements to cope with CPR problems).

${ }^{8}$ SUSAN J. BUCK, THE GLOBAL COMMONS: AN INTRODUCTION 5 (1998) (explaining that CPRs implicate property rights and are defined as "subtractable resources managed under a property regime in which a legally defined user pool cannot be efficiently excluded from the resource domain.").

${ }^{9}$ See id.

${ }^{10} \mathrm{Id}$.

${ }^{11}$ See Vincent Ostrom \& Elinor Ostrom, Public Goods and Public Choices, in ELINOR OSTROM AND THE BLOOMINGTON SCHOOL OF POLITICAL ECONOMY Vol. 2, at 3, 6 (Daniel H. Cole \& Michael McGinnis eds., 2015).

${ }^{12}$ See id.

${ }^{13} \mathrm{Id}$. 
system shared with others." 14 As with overfishing, certain corporate behaviors are unsustainable. ${ }^{15}$

"What is a corporation?" is a question debated by scholars, without resolution, for many years. This Article attacks that question through the lens of CPR Theory, approaching the analysis by viewing the corporation as a good. Since stock ownership in a public corporation is considered a property right held by individuals, the shareholders, and stock ownership both (1) excludes (e.g., ease of exclusion) others from owning the same rights, and (2) prevents others from enjoying the fruits of dividends and share price gains (e.g., high subtractability), then a corporation can be viewed as a private good.. To employ a limited, but arguably useful metaphor, one might describe the corporation as a walled garden, accessible only to those with keys, which may be purchased as shares of stock. This metaphor embraces the view of corporate design as a top down, private fencing of goods/property for the benefit of shareholders. While corporate directors have flexible powers to allocate limited resources, corporate law in the United States is "tilted heavily"16 towards shareholders, and their power is brought to bear upon boards of directors through the choice of activist methods available to them. ${ }^{17}$ Furthermore, as described by Justice Strine, Jr. of the Delaware Supreme Court:

Even if a corporate manager wishes to pursue profits in a high-minded manner that respects the best interests of other corporate constituencies, if the law allows others not to do so and gives them a chance to seek profits at lower cost, for example, that corporate manager may feel obliged to compromise his sense of integrity because of a fear that stockholders will demand that he keep pace with his competitors who are less other-regarding. ${ }^{18}$

Thus, while initially it might seem counter intuitive, we propose that benefit corporation legislation is ultimately about shifting corporations away from being considered private goods and

${ }^{14}$ Elinor Ostrom, Roy GARDNER, \& JAMES WALKer, RULES, GAMES, AND COMMON-POOL RESOURCES 4 (2006).

15 See Nicholas A. Ashford, Ralph P. Hall, TeChnOlOGY, Globalizatoin, AND Sustainable DEVElopMEnT: TRANSFORMING THE INDUSTRIAL STATE 292 (2011).

${ }^{16}$ Leo E. Strine, Jr., Making it Easier for Directors to "Do the Right

Thing?, 4 HARV. BUS. L.REV. 235, 236 (2014).

${ }^{17}$ Id. at 239.

${ }^{18} I d$. 
towards being CPRs that should be managed in a collaborative way to benefit a wider set of stakeholders in society. We contend, for the first time in the literature, ${ }^{19}$ that benefit corporation legislation is moving corporate identity and its governance further on the spectrum towards being a CPR because it requires sharing of corporate resources through socially responsible behaviour (difficulty of exclusion) while maintaining the profit paradigm of corporate existence (high subtractability). In essence, the garden is still walled, yet the keys are more widely dispersed. Through this lens, this Article investigates the processes and purposes of enacting benefit corporation statutes as a vehicle to better understand what role individuals, civil society, and other institutions play in reshaping the relationship between business and society. Furthermore, benefit corporation legislation supports cooperative (socially responsible) decision making that is the hallmark of a decentralized, multi-faceted management of common resources.

Part I offers a basic background in the polycentric governance of CPRs. Part II situates the benefit corporation within corporate theory and law, showing how the corporation as a CPR has historical resonance. Part III summarizes two case studiesConnecticut and Delaware - to provide in-depth, qualitative assessments of these states' experiences with benefit corporation legislation that has been missing in the literature to date. We analyze these case studies through the work of Professor Elinor Ostrom and her colleagues' work on collective action ${ }^{20}$ and polycentric institutional analysis, ${ }^{21}$ focusing on the Institutional Analysis and Design (IAD) Framework, in Part IV. ${ }^{22}$ Finally, Part $\mathrm{V}$ couches the discussion with global developments focusing on the European Union, and concludes with a discussion of the lessons learned and the potential for further governance changes with this new corporate form. ${ }^{23}$

${ }^{19}$ Cf. Stephen K. Park \& Gerlinde Berger-Walliser, A Firm-Driven Approach to Global Governance and Sustainability, 52 AM. BuS. L.J. 255, 269, 274 (2015).

${ }^{20}$ Elinor Ostrom, A Polycentric Approach for Coping with Climate Change 6 (World Bank, Policy Research Working Paper No. 5095, 2009), http://www.iadb.org/intal/intalcdi/pe/2009/04268.pdf

${ }^{21}$ See id.

${ }^{22}$ See Elinor Ostrom, Polycentric Systems: Multilevel Governance Involving a Diversity of Organizations, in GLOBAL ENVIRONMENTAL COMMONS: ANALYTICAL AND POLITICAL CHALLENGES INVOLVING A DIVERSITY OF ORGANIZATIONS 105, 118 tbl. 5.3 (Eric Brousseau et al. eds., 2012).

${ }^{23}$ For more recent analyses of public benefit corporations, see generally J. Haskell Murray, Choose Your Own Master: Social Enterprise, Certifications, and Benefit Corporation Statutes, 2 AM. U. Bus. L. REV. 1 (2012); Alicia E. Plerhoples, Delaware Public Benefit Corporations 90 Days Out: Who's Opting In?, 14 U.C. DAVIS BUS. L.J. 247 (2014); Kyle Westaway \& Dirk Sampselle, 


\section{PolyCENTRIC GovernanCE AND BUILding SOCIALLY RESPONSIBLE BUSINESSES}

According to Professor Michael McGinnis, "[t]he basic idea [of polycentric governance] is that any group ... facing some collective action problem should be able to address that problem in whatever way they best see fit." 24 This could include using existing governance structures or crafting new systems. ${ }^{25}$ In other words, "[a] system of governance is fully polycentric if it facilitates creative problem-solving at all levels ...."26 This multi-level, multi-purpose, multi-functional, and multi-sectoral model, ${ }^{27}$ championed by scholars including Nobel Laureate Elinor Ostrom and Professor Vincent Ostrom, challenges orthodoxy by demonstrating the benefits of self-organization, networking regulations "at multiple [governance] scales," 28 and examining the extent to which national and private control can in some cases coexist with communal management. It also posits that, due to the existence of free riders in a multipolar world, "a single governmental unit" is often incapable of managing collective action problems. ${ }^{29}$ Instead, a polycentric approach recognizes that diverse organizations working at multiple governance levels can create different types of policies that can increase levels of cooperation and compliance, enhancing "flexibility across issues and adaptability over time." 30

The Benefit Corporation: An Economic Analysis with Recommendations to Courts, Boards, and Legislatures, EMORY L.J. 999 (2013).

${ }^{24}$ Michael D. McGinnis, Costs and Challenges of Polycentric Governance: An Equilibrium Concept and Examples from U.S. Health Care, Workshop on Self-Governance, Polycentricity, and Development, at 1 (Conference on Self-Governance, Polycentricity, and Development, Renmin University, in Beijing, China) (2011),

http://php.indiana.edu/ mcginnis/Beijing_core.pdf.

${ }^{25} \mathrm{Id}$. at $1-2$.

${ }^{26} \mathrm{Id}$. at 3 .

${ }^{27}$ Michael D. McGinnis, An Introduction to IAD and the Language of the Ostrom Workshop: A Simple Guide to a Complex Framework, 39 POL'Y

STUD. J. 163, 171-72 (2011), available at http://php.indiana.edu/ mcginnis/iad_guide.pdf.

${ }^{28}$ Elinor Ostrom, Polycentric Systems as One Approach for Solving Collective-Action Problems 1 (Ind. Univ. Workshop in Political Theory and Policy Analysis, Working Paper Series No. 08-6, 2008), http://dlc.dlib.indiana.edu/dlc/bitstream/handle/10535/4417/W08-

6_Ostrom_DLC.pdf?sequence=1.

${ }^{29}$ See id. at 35.

${ }^{30}$ Robert O. Keohane \& David G. Victor, The Regime Complex for Climate Change 9 PERSP. ON POL. 7, 9 (2011); cf. Julia Black, Constructing and Contesting Legitimacy and Accountability in Polycentric Regulatory Regimes, 2 REG. \& GOVERNANCE 137, 157 (2008) (discussing the legitimacy of polycentric 
In the 1970s and 1980s a series of landmark field studies challenged the prevailing notion that the provision of public services - like police and education — was made better and more cost-effective by slashing and consolidating the number of departments and districts. ${ }^{31}$ Professor Elinor Ostrom built on these studies to determine whether polycentric governance regimes could mitigate collective action problems associated with CPRs. She challenged the conventional theory of collective action, ${ }^{32}$ which held that rational actors would not cooperate to achieve a socially optimal outcome. Proponents of the conventional theory thought that only top-down, state-imposed regulations could create the proper incentives for optimal collective action for use of CPRs. However, field studies that she and others conducted on the provision of water resources in California, ${ }^{33}$ the design and maintenance of irrigation systems in Nepal, ${ }^{34}$ and the protection of forests in Latin America ${ }^{35}$ showed otherwise that, contrary to the conventional theory, many individuals will in fact cooperate in the face of collective action problems. ${ }^{36}$ These observations in the field were consistent with laboratory experiments that found

regimes, and arguing that "[a]ll regulatory regimes are polycentric to varying degrees").

${ }^{31}$ See, e.g., Elinor Ostrom et Al., Patterns of Metropolitan POLICING (1978) (reporting on a major study of police organization in 80 metropolitan areas); E.A. Hanushek, The Econoimcs of Schooling: Production and Efficiency in Public Schools, 24 J. ECON. LIT. 1141 (1986) (finding no better performance in larger school districts); Roger Parks, Metropolitan Structure and Systemic Performance: The Case of Police Service Delivery, in PoLICY IMPLEMENTATION IN FEDERAL AND UNITARY SYSTEMS 161 (Kenneth Hanf \& Theo A.J. Toonen, eds. 1985); Paul Teske et al., Establishing the Micro Foundations of a Macro Theory: Information, Movers, and the Competitive Local Market for Public Goods, 87 AM. POL. SCI. REV. 702 (1993); POLYCENTRICITY AND LOCAL PUBLIC ECONOMIES: READINGS FROM THE WORKSHOP IN POLITICAL THEORY AND POLICY ANALYSIS (Michael D. McGinnis, ed. 1999) (collecting these studies).

${ }^{32}$ The traditional theory of the collective action problem was first articulated in the 1960s Mancur Olsen, an economist and social scientist from the University of Maryland. See generally MANCUR OLSON, THE LOGIC OF COLlECtIVE ACTION: Public GOODS AND THE THEORY OF GROUPS (1965) (providing the first comprehensive explication of the collective action problem). Professor Olson theorized "only a separate and 'selective' incentive will stimulate a rational individual in a latent group to act in a group-oriented way." Id. at 51 .

${ }^{33}$ See, e.g., Elinor Ostrom, Public Entrepreneurship: A Case Study in Ground Water Basin Management (1965) (unpublished Ph.D. dissertation, Univ. of Calif., Los Angeles).

${ }^{34} \mathrm{See}$, e.g., IMPROVING IRRIGATION GOVERNANCE AND MANAGEMENT IN NEPAL (Ganesh Shivakoti \& Elinor Ostrom, eds., 2002).

${ }^{35}$ See, e.g., Elinor Ostrom \& Harini Nagendra, Insights on Linking Forests, Trees, and People from the Air, on the Ground, and in the Laboratory, 103 PROC. NAT'L ACAD. SCI. 19224, 19224-25 (2006).

${ }^{36}$ Ostrom, supra note 20, at 10. 
externally imposed regulations that were intended to maximize joint returns in the face of collective action problems actually "crowded out" individuals' voluntary cooperative behavior. ${ }^{37}$

Since this groundbreaking work, scholars from various disciplines have utilized the concept of polycentricity in a number of different ways. In general, polycentric institutional analysis is marked by a regulatory system - sometimes referred to as a regime complex ${ }^{38}$ - that is characterized by "multiple governing authorities at differing scales rather than a monocentric unit," according to Professor Ostrom. ${ }^{39}$ In a polycentric system, therefore, the state is not the only source or foundation of authority and, in fact, may play little or no role at all. ${ }^{40}$ Instead, a complex array of state and non-state interdependent actors and decision making centers, which may be formally independent of one another, form networks and interact among themselves, each adding some value, while reinforcing each other and compensating for each other's limitations and weaknesses. ${ }^{41}$ Each individual actor within the system is typically free from domination by the others and can make its own rules and develop its own norms within its domain of influence. ${ }^{42}$ Nevertheless, there is also opportunity within the system for "mutual monitoring, learning, and adaptation of better strategies over time." 43

It may be easiest to understand polycentric governance in juxtaposition to the alternative-monocentrism, which is a political system where the authority to enforce rules is "vested in a single decision structure that has an ultimate monopoly over the

${ }^{37}$ See Bruno S. Frey \& Felix Oberholzer-Gee, The Cost of Price Incentives: An Empirical Analysis of Motivation Crowding-Out, 87 AM. ECON. REV. 746 (1999); Elinor Ostrom, Beyond Markets and States: Polycentric Governance of Complex Economic Systems, 100 AM. ECON. REV. 641, 656 (2010).

${ }^{38}$ See, e.g., Daniel H. Cole, From Global to Polycentric Climate Governance, 2 CLIMATE L. 395 (2011) (treating regime complex and polycentricity as practically the same thing); Scott J. Shackelford, Governing the Final Frontier: A Polycentric Approach to Managing Space Weaponization and Orbital Debris, 51 AM. BuS. L.J. 429, 431-32 (2014) (noting the use of "regime complex" as synonymous with polycentric governance).

${ }^{39}$ Elinor Ostrom, Polycentric Systems for Coping with Collective Action and Global Environmental Change, 20 Global EnVtL. CHAnGE 550, 552 (2010).

${ }^{40}$ Julie Black, Constructing and Contesting Legitimacy and Accountability in Polycentric Regulatory Regimes, 2 REG. \& GOVERNANCE 137, 137-38 (2008).

${ }^{41}$ Vincent Ostrom et al., The Organization of Government in Metropolitan Areas: A Theoretical Inquiry, 55 AM. POL. SCI. REV. 831, 831-32 (1961).

42 Ostrom, supra note 39, at 552.

${ }^{43} I d$. 
legitimate exercise of coercive capabilities." 44 At its corebuilding from notions of legitimacy, power, and multiple decision centers-polycentric governance is concerned with the rule of law. In this manner, the U.S. constitution has been described as an "experiment in polycentricity" with federalism being one way to operationalize the concept. ${ }^{45}$ What is it that makes polycentric systems so special? In short, the capacity for spontaneous selfcorrection. ${ }^{46}$ In the words of Professor Elinor Ostrom:

[A] political system that has multiple centers of power at differing scales provides more opportunity for citizens and their officials to innovate and to intervene so as to correct maldistributions of authority and outcomes. Thus, polycentric systems are more likely than monocentric systems to provide incentives leading to self-organized, selfcorrective institutional change. ${ }^{47}$

A key element of polycentricity is this spontaneity, which to Professor Vincent Ostrom, meant that "patterns of organization within a polycentric system will be self-generating or selforganizing" in the sense that "individuals acting at all levels will have the incentives to create or institute appropriate patterns of ordered relationships." ${ }^{48}$ What factors are most important to engender such spontaneous self-correction? Free entry, and the incentivized enforcement of rules, which are in turn are continually revised. ${ }^{49}$ In other words, anyone should be able to play the game, and even collaborate to change the rules through orderly means. It is a goal of this Article to ascertain whether these conditions are met in the context of socially responsible corporate law that is being operationalized in the form of benefit corporations. ${ }^{50}$

\section{Corporate Visions: Situating The BENEFIT CORPORATION As A COMMON POOL RESOURCE}

${ }^{44}$ Paul D. Aligica \& Vlad Tarko, Polycentricity: From Polanyi to Ostrom, and Beyond, 25 GOVERNANCE 237, 244 (2012).

${ }^{45} \mathrm{Id}$. at 245.

${ }^{46} I d$.

${ }^{47} \mathrm{Id}$.

${ }^{48} I d$.

${ }^{49} \mathrm{Id}$. at 246.

${ }^{50}$ It is also important to couch this work as part of the overarching literature on institutional analysis, which leverages work on property rights and transaction costs. See LeE J. Alston, Thrainn EgGERTSSON, \& Douglass C. NORTH, EMPIRICAL STUDiES IN INSTITUTIONAL CHANGE 92 (1996). 
Views of the firm are informed by interdisciplinary scholarship from economics, finance, management, and law, among myriad other disciplines. Because benefit corporations respond to and incorporate elements of previously held theories about what firms should do, ${ }^{51}$ including why such an organizational form exists, ${ }^{52}$ a brief discussion of the history and debate surrounding the fundamental nature of the corporation is a necessary starting point for informed discussion about its evolution from private good to CPR. The firm's relationships with society, and related fiduciary duties, can be transformed when individuals join together in the new organizational form known as the benefit corporation.

\section{A. Theory of the Firm}

One view of the firm is known as the neoclassical theory, a conception of the corporation as a sort of black box. ${ }^{53}$ The boundaries of the this corporate box separate external, market driven forces and players from internal capital and employees. ${ }^{54}$ The theory focuses on the actions of managers/directors to derive profits from the marketplace, and stands upon the premise that those actions will serve to maximize profits to the owners, who are the shareholders. ${ }^{55}$ But, according to Professor Oliver Hart, neoclassical theory "does not explain how production is organized within a firm, how conflicts of interest between the firm's various constituencies-its owners, managers, workers, and consumers-are resolved, or, more generally, how the goal of profit-maximization

51 The two terms, corporation and firm, are distinct in some ways, but for purposes of this article are used interchangeably. For a more detailed discussion of the meaning of the terms see Matthew T. Bodie, The PostRevolutionary Period in Corporate Law: Returning to the Theory of the Firm, 35 SEATtLE U. L. REV. 1033, 1043-1044 (2012) (theories of the firm underlie the reasons why the corporate form exists).

52 The literature on the theory of the firm is voluminous. For a representative background of legal discussions, see Stephen M. Bainbridge, Director Primacy: The Means and Ends of Corporate Governance, 97 NW. U. L. REV. 547, 547-550 (2003) (arguing that the firm is a nexus of contracts); Bodie, supra note 51, at 1040-59 (comparing financial and legal theories); Thomas S. Ulen, The Coasean Firm in Law and Economics, 18 J. CORP. L. 301, 301 (1993); Alan Wolfe, The Modern Corporation: Private Agent or Public Actor? 50 WASH. \& LEE L. REV. 1673, 1673 (1993) (noting that "the nature of corporations has always been contested").

${ }^{53}$ See Robert M. Grant, Toward a Knowledge-Based Theory of the Firm, 17 StRATEGIC MGMT. J. 109, 110 (1996).

${ }^{54}$ See Bodie, supra note 51, at 1053 ("Although the neoclassical firm was largely undefined, employees and capital assets were considered to be inside the firm, while customers and suppliers were outside.").

55 See Oliver Hart, Contractual Freedom in Corporate Law, Columbia L. Rev. 1757, 1758 (1989). 
is achieved." 56

In the 1930's, a famous discussion in the Harvard Law Review raged between two prominent scholars over a different conception of the nature of a corporation as to whether corporate directors owe a fiduciary duty only to shareholders, or to society as well. ${ }^{57}$ On one side, Professor Adolph Berle promoted the shareholder as owner view (consistent with the corporation as a private good analogy), and ascribed the accumulation of shareholder wealth as the exclusive reason for director action. ${ }^{58}$ On the other side, Professor E. Merrick Dodd described the corporation as being at least in part publicly constituted (evoking CPR Theory), rather than privately constructed solely for profit, therefore owing duties more broadly to stakeholders as well as shareholders. ${ }^{59}$ This debate continued for many years. ${ }^{60}$

Professor Roald Coase became a leading voice in economics in the later 1930's, theorizing that the firm functions to reduce transaction costs between managers and workers. ${ }^{61}$ A halfcentury later, a nexus of contracts theory built upon the approach by Professor Coase, broadening the concept of managing transaction costs to emphasize the effect of corporate law to more efficiently standardize a web of contracts between owners, managers, and employees. ${ }^{62}$ The nexus of contracts theory has been criticized because of its reliance on a shareholder ownership foundation that is legally suspect, ${ }^{63}$ and because it focuses too much on the financial aspects of the firm and too little on

${ }^{56} I d$. (emphasis added).

${ }^{57}$ See Antony Page, New Corporate Forms and Green Business, WM. \& MARY EnVTL. L. \& POL'Y ReV. 347, 355 (2013); Antony Page \& Robert A. Katz, Is Social Enterprise the New Corporate Social Responsibility? 34 SeAtTlE U. L. ReV, 1351, 1351-52 (2011).

${ }^{58}$ See Adolph A. Berle, Corporate Powers as Powers in Trust, 44 HARV. L. REV. 1049, 1049 (1931).

${ }^{59}$ See E. Merrick Dodd, For Whom are Corporate Managers Trustees?, 45 HARV. L. REV. 1145, 1145 (1932).

${ }^{60}$ For a description of the prolonged debate, see Joseph L. Weiner, The Berle-Dodd Dialogue on the Concept of the Corporation, 64 CoLUM. L. REV. 1458, 1458 (1964). The debate has swung like a pendulum for decades. See Anant K. Sundaram \& Andrew C. Inkpen, The Corporate Objective Revisited, 15 ORG. SCI. 350, 351 (2004) (describing a 150 year debate in this field).

${ }^{61}$ See Bodie, supra note 51, at 1071 . The focus on addressing transaction costs as a reason for the firm has also been framed in relationship to agency costs and property rights. See Ulen, supra note 52, at 312-14, 316.

${ }^{62}$ See Michael C. Jensen \& William H. Meckling, Theory of the Firm: Managerial Behavior, Agency Costs and Ownership Structure, 3 J. FIN. ECON. 305, 310 (1976) ("Contractual relations are the essence of the firm, not only with employees but with suppliers, customers, creditors, etc.").

${ }^{63}$ See Jacob E. Hasler, Contracting for Public Good: How Benefit Corporations Empower Investors and Redefine Shareholder Value, 100 VA. L. REV. 1279, 1291 (2014) ("shareholders can not be owners in the legal sense"). 
operational aspects. ${ }^{64}$ Nevertheless, the nexus of contracts theory undergirds arguments that the reason for the firm is to focus on efficiency, and on producing the greatest profit for its owners, the shareholders. ${ }^{65}$ A second strand of the economic theory of the firm states that contracts are incomplete, and that it is therefore the residual property ownership by shareholders that defines the duties and fundamental relationships in firms. ${ }^{66}$ While distinct in approach, the property theory mirrors the nexus of contracts view of shareholder supremacy and the profit motivated purpose of the firm in order to protect the private property rights of the owners, shareholders, over the public benefit. ${ }^{67}$

Professor Dodd's more expansive view of the firm never died, although at times it seemed eclipsed by the dominant shareholder primacy and profit focus. ${ }^{68}$ In fact, at about the same time that the dominance seemed complete, ${ }^{69}$ a strong alternative to these approaches was emerging; the team production theory of the firm. ${ }^{70}$ Professors Margaret Blair and Lynn Stout rejected the nexus of contracts and property rights approaches and theorized instead that:

[A] public corporation is a team of people who enter into a complex agreement to work together for their mutual gain. Participants-including shareholders, employees, and perhaps other stakeholders such as creditors or the local

${ }^{64}$ See Bodie, supra note 51, at 1039; Lynn Stout, THE SHAREHOLDER VALUE MYth: How PUTTING SHAREHOLDERS FIRST HARMS INVESTORS, CORPORATIONS, AND THE PUBLIC 3 (2012).

${ }^{65}$ See Margaret M. Blair \& Lynn A. Stout, A Team Production Theory of Corporate Law, 85 Va. L. Rev. 247, 252-53 (1999); Justin Blount \& Patricia Nunley, Social Enterprise, Corporate Objectives, and the Corporate Governance Narrative, 52 AM BuS. L.J 201, 224 ("The soundest logical argument for the default position of maximization of shareholder wealth is posited by the contractarian theory of the firm."); Henry Hansmann \& Reinier Kraakman, The End of History for Corporate Law, 89 GEO. L.J. 439, 468 (2001) (the "triumph of the shareholder-oriented model of the corporation over its principal competitors is now assured").

${ }^{66}$ Blair \& Stout, supra note 65, at 262 ("In this view, there exists in every firm some principal who is the ultimate "owner" of the bundle of assets used by the firm in production. The owner is understood to delegate residual control rights to her agents (in the corporate context, the board of directors) who in turn are charged with managing the assets in the principal's interest, perhaps through several more layers of delegation.").

${ }^{67}$ This view also intersects with institutional analysis. See ALSTON et al., supra note 50.

${ }^{68}$ See Sundaram \& Inkpen, supra note 60, at 350 ("In the field of finance, the logic of shareholder value maximization is accepted as being so obvious that textbooks just assert it, rather than argue for it.").

${ }^{69}$ See Tamara C. Belinfanti, Contemplating the Gap-Filling Role of Social Intrapreneurship, 94 OR. L. REV. 67, 88-90 (2015).

${ }^{70}$ See Blair \& Stout, supra note 65, at 265-67. 
community-enter into a 'pactums ubjectionis' under which they yield control over outputs and key inputs (time, intellectual skills, or financial capital) to the [corporate] hierarchy. ${ }^{71}$

Thus, under the team production theory shareholder wealth is not the only, or even the primary, reason for a corporation to exist; instead, there are a multiplicity of interests funneled into a corporate form to produce a wider grant of benefits to various participants in the firm environment. ${ }^{72}$ This evokes the CPR underpinnings of polycentric institutional analysis, particularly its focus on nested enterprises discussed further in Part IV. ${ }^{73}$

Reminiscent of the team production theory of the later twentieth century, management scholars ${ }^{74}$ in particular have proposed stakeholder theories of corporate existence and a broader conception of corporate social responsibility to society. ${ }^{75}$ This approach harkens back to the premise argued by Professor Dodd in the early 1930's that a multitude of interests define the corporation. ${ }^{76}$ Stakeholders are broadly defined as those groups who have an interest in the success of the firm, whether by contract, employment, or social impact. ${ }^{77}$ Shareholders are only one among several groups of stakeholders, so that their interest in profit may or may not be primary depending on the decision and the totality of stakeholder interests. ${ }^{78}$ Stakeholder theory, in general, broadens the team production theory by explicitly

${ }^{71} I d$. at 278 ("They thus agree not to specific terms or outcomes (as in a traditional 'contract'), but to participation in a process of internal goal setting and dispute resolution. Hence the mediating hierarchy of a corporation can be viewed as a substitute for explicit contracting that is especially useful in situations where team production requires several different team members to make various kinds of enterprise-specific investments in projects that are complex, ongoing, and unpredictable.”).

${ }^{72}$ Human capital and the knowledge base therefrom are "key assets" of the corporation. Id. at 261.

${ }^{73}$ The comparison is not perfect, but reflects a fundamental recognition of the various interests and their organization with regards to the operation of the corporation. See infra Part IV(A).

${ }^{74}$ See Marianne M. Jennings \& Stephen Happel, The Post-Enron Era For Stakeholder Theory: A New Look At Corporate Governance and the Coase Theorem, 54 MERCER L. REV. 873, 880 (2003).

75 There are different versions or approaches to stakeholder theory; within the confines of this background section the discussion fits under the umbrella of the theory broadly. See Andrew Keay, Stakeholder Theory in Corporate Law: Has It Got What It Takes?, 9 RICH. J. GLOBAL L. \& BUS. 249, 252-53 (2010) ("The wide-ranging views that exist are consonant with the fact that stakeholding is a broad concept.").

${ }^{76}$ See Dodd, supra note 59, and accompanying text.

${ }^{77}$ See Keay, supra note 75, at 253-54 (tracing the history of corporate stakeholder theories).

${ }^{78} \mathrm{See}$ 
including external stakeholder interests in the decision making process. ${ }^{79}$

\section{B. Legal Application of the Theory of the Firm}

In U.S. legal scholarship, according to Professor Alan Wolfe, "Because there has never been agreement in this country over what corporations are, skepticism over any assertion that they must . . . be any one thing is appropriate." 80 Indeed, legal conceptions of a corporation have not developed in isolation. The financial emphasis on shareholder primacy and profit has been reflected in certain lines of judicial decisions, while constituency statutes have responded to the narrow application of profit maximization by codifying the ability of firms to consider interests other than those of shareholders. Furthermore, the definition of what a corporation is, in fundamental ways, has found its way into debates about political speech, ${ }^{81}$ and religion, ${ }^{82}$ in the U.S. Supreme Court. The legal precedent is punctuated by several significant cases.

Dodge v. Ford ${ }^{83}$ decided in 1919 , overturned Henry Ford's decision to refuse issuing dividends so that he could lower the prices of cars and return some of the benefits to employees, because he believed that the company did not solely exist for making profits, but was also "Organized to do as much good as we can, everywhere, for everybody concerned." 84 In other words, Ford's vision was in line with the CPR theory of the firm discussed above, such as by spreading the benefits of industrialization more broadly to other groups besides shareholders, such as employees. ${ }^{85}$ The Court's decision in Dodge v. Ford arguably rejects the legality of these theories by stating, "A business corporation is organized

${ }^{79}$ See generally Timothy Fort, The Corporation as Mediating Institution: An Efficacious Synthesis of Stakeholder Theory and Corporate Constituency Statutes, 73 Notre DAME L. REV. 173, 183-86 (1997); Amir N. Licht, The Maximands of Corporate Governance: A Theory of Values and Cognitive Style, 29 DEL. J. CoRP. L. 649, 722-30 (2004); Brian M. McCall, The Corporation as Imperfect Society, 36 DEL. J. CORP. L. 509, 521-23 (2011).

${ }^{80}$ See Wolfe, supra note 51, at 1673 (describing 3 possible definitions of a corporation, either as a separate entity, a creation of state statute, or a private entity).

${ }^{81}$ Citizens United v. Federal Election Com'n, 558 U.S. 310, 318 (2010) (corporate political speech may be limited but not prohibited).

82 Burwell v. Hobby Lobby, 134 S.Ct. 2751, 2759 (2014) (religious freedom of closely held corporations).

${ }^{83} 170$ N.W. 668 (1919).

${ }^{84}$ Linda Kawaguchi, Introduction to Dodge v. Ford Motor Co.: Primary and Source and Commentary Material, 17 CHAPMAN L. REV. 493, 495, 503 (2014).

${ }^{85} I d$. 
and carried on primarily for the profit of the stockholders." 86 Thus, Dodge v. Ford establishes the corollary that the director's fiduciary duty is owed to the shareholder, to deliver profits. ${ }^{87}$ The potential conflict and ambiguity of fiduciary duties is an important part of the debate about benefit corporations. It should be noted, however, that shareholder primacy is distinct from shareholder wealth maximization, and that while they will likely go hand in hand, a director's fiduciary duty is guided by the business judgment rule, which grants broad discretion to a director's decision as long as it is rationally related to a business purpose. ${ }^{88}$

Half a century later in the 1980's, amidst a wave of corporate takeovers and resulting plant closings, states began to pass statutes that explicitly allowed directors to consider the interests of employers, communities, and other third party interests as part of business decision making, ${ }^{89}$ a precursor to the rise of benefit corporations. In one group of states, the statutes apply only to takeover situations, whereas another group of states applies the standard across the board to all director decisions. ${ }^{90}$ Thus, while the majority of states have passed constituency statutes, they vary in application, and Delaware is a glaring member in the minority of states that do not have a constituency statute. ${ }^{91}$

${ }^{86}$ Dodge v. Ford, 170 N.W. at 683 (emphasis added).

${ }^{87}$ See Paul B. Miller \& Andrew S. Gold, Fiduciary Governance, 57 WM. \& MARY L. REV. 513, 536-39 (discussing the different theories and suggesting that Delaware law is intentionally vague on the exclusivity of the duty owed by directors to shareholders).

${ }^{88}$ See Justin Blount \& Kwabena Offei-Danso, The Benefit Corporation: A Questionable Solution To a Non-Existent Problem, 44 ST. MARY'S L.J. 617, 636-37 (2013). For a concise description of the relationship between director duties, shareholders, and the delivery of profits, see Lynn Stout, Corporations Don't Have to Maximize Profits, N.Y. TIMES (April 16, 2015, 6:46 AM). http://www.nytimes.com/roomfordebate/2015/04/16/what-arecorporations-obligations-to-shareholders/corporations-dont-have-to-maximizeprofits. For a critical review of the case, see Lynn A. Stout, Why We Should Stop Teaching Dodge v. Ford, 3 VA. L. \& BuS. REV. 163, 168-72 (2008).

${ }^{89}$ See Kathleen Hale, Corporate Law and Stakeholders: Moving Beyond Stakeholder Statutes, 823 ARIZ. L. REV. 823, 831 (2003).

${ }^{90} \mathrm{Id}$. at 836.

${ }^{91}$ See Steven J. Haymore, Public(ly Oriented) Companies: B Corporations and the Delaware Stakeholder Provision Dilemma, 64 VAND. L. REV. 1311, 1340-41 (2011) (discussing whether a constituency statute would be recommended for Delaware and benefit corporation law). See generally Anthony Bisconti, The Double Bottom Line: Can Constituency Statutes Protect Socially Responsible Corporations Stuck in Revlon Land?, 42 LOY. L.A. L. REV. 765 (2009); Eric W. Orts, Beyond Shareholders: Interpreting Corporate Constituency Statutes, 61 GEO. WASH. L. REV. 14, (1992) (addressing the state of the law); Maxwell Silver-Thompson, Reasonable Consideration of NonShareholders: Redrafting State Constituency Statutes to Encourage SociallyMinded Business Decisions, 13 CARdozo PuB. L. POL'Y \& ETHICs J. 253, 258 (2014) (reporting that 41 states had constituency type statutes by 1999). 
Delaware's law dominates corporate legal thinking due to its history, specialized courts, developed jurisprudence, and locale for prominent corporations. A series of Delaware cases defining director duties during a takeover or change of control ${ }^{92}$ set the stage for the emergence of the benefit corporation. For example, in Revlon v. MacAndrews, ${ }^{93}$ a Delaware court established that in certain change of control decisions a corporation may not consider any interests other than the highest price possible for shareholders. ${ }^{94}$ In addition, under the Unocal Corp. v. Mesa Petrol decision, a higher level of review is required when corporate a director takes defensive actions against a takeover. ${ }^{95}$ A more recent case overturned anti-takeover tactics designed to avoid a takeover because they were not taken in a "good faith pursuit of a proper corporate purpose." 96 The majority of shareholders in a closely held corporation, Craigslist, adopted draconian poison pill provisions in order to prevent its minority shareholder, eBay, from implementing marketing and commercial modernization to expand the company in ways that conflicted with their business model. ${ }^{97}$ In eBay Domestic Holdings v. Newmark, ${ }^{98}$ the Delaware court ruled against Craigslist because, "Directors of a for-profit Delaware corporation cannot deploy a rights plan to defend a business strategy that openly eschews stockholder wealth maximization." 99 Although the facts in this case were unique, ${ }^{100}$ it is in a line of cases ${ }^{101}$ that can give a director pause before taking non-shareholder interests into consideration in corporate decision making. ${ }^{102}$

In summary, scholars and jurists have debated for decades the nature of a firm's relationship with its shareholders and with society. Professor Dodd's early description of the firm, and theories such as the

${ }^{92}$ See William M. Lafferty et al., A Brief Introduction to the Fiduciary Duties of Directors Under Delaware Law, 116 PA. ST. L. REV. 837, 849-860 (2012).

${ }^{93}$ Revlon, Inc. v. MacAndrews \& Forbes Holdings, Inc., 506 A.2d 173, 182 (Del. 1986).

${ }^{94}$ Revlon at 182. Also see Lafferty, supra note 92, at 853-53 (explaining three situations when the Revlon rule will apply).

95 Unocol Corp. v. Mesa Petroleum Co., 493 A.2d 946 (Del. 1985). See also, Lafferty, supra note 92, at fn 76.

96 eBay Domestic Holdings, Inc. v. Newmark, 16 A.3d 1, 34 (Del., 2010).

${ }^{97} \mathrm{Id}$. at $28-31$.

9816 A.3d 1.

${ }^{99}$ Id. at 35.

${ }^{100}$ Id. See Kristin A. Neubauer, Benefit Corporations: Providing a New Shield For Corporations With Ideals Beyond Profits, 11 J. BuS. \& TECH. L. 109, 120-22 (2016).

101 See Sean W. Brownridge, A Wolf in Sheep's Clothing: Unocal and the Defensive Mechanism Hidden in Corporate Benefit Purpose, 60 VILL. L. REV. 903, 907-911 (2015) (surveying the Unocal case and its "legacy").

102 See Hasler, supra note 62, at 12999-12300. 
team production and stakeholder views, support a broader conception of the corporation in line with CPR theory and closer to the conception of a corporation as a shared resource, albeit within a limited sphere.

But Delaware case law, and financial theory rigidity around stockholder primacy and wealth maximization, has guided conservative legal advice limiting the ability of mangers to take into account the interests of stakeholders other than shareholders. ${ }^{103}$

This, then, is the field of play that twenty-first century entrepreneurs and business leaders faced. It is into this environment, and in response to the argument that only limited shareholder interests can be considered by managers and directors, in which the benefit corporation emerged. The creative problem solving that is part of polycentric governance is reflected in the story of how the benefit corporation came to be created, and ultimately in the quiet legal revolution its founders achieved.

\section{Benefit Corporations: A New (Old?) Conception of the Firm}

Professor Reuven Avi-Yonah's research traces the birth and evolution of corporations and their role in society. ${ }^{104} \mathrm{He}$ argues that there were four primary transformations in the history of corporate law since Roman times, beginning with the creation of the firm as a legal person under Roman law, yet also as a nonprofit organization motivated toward promoting the public good. ${ }^{105}$ The second transformation occurred between the mid-fourteenth and nineteenth centuries and permitted corporations to be organized as for-profit concerns. ${ }^{106}$ The third stage witnessed corporations moving from closely-held to widely-held management structures, ${ }^{107}$ to an extent eschewing localized selfgovernance. The fourth and final innovation involved the movement from national to multinational enterprises. ${ }^{108}$ Throughout this evolution, we see a movement away from the local non-profit, public good orientation of firms to multinational for-profit enterprises, a governance trend line that the rise of benefit corporations, in a sense, reverses by harkening back to the original public good purpose of the first Roman corporations.

103 See Bodie, supra note 51, at 1033-34; Kyle Westaway \& Dirk Sampselle, The Benefit Corporation: An Economic Analysis With

Recommendations to Courts, Boards, and Legislatures, 62 EMORY L. J. 999, 1004-1005.

104 See Timothy L. Fort, Business, InTEGRITy, AND PEACE: BEyond GEOPOLITICAL AND DISCIPLINARY BOUNDARIES 86 (2011).

${ }^{105} \mathrm{Id}$.

${ }^{106} \mathrm{Id}$. at 86-87.

${ }^{107} \mathrm{Id}$. at 87.

${ }^{108} I d$. 
Taken together, the study of how corporations operate, who owns them, and why they exist is generally considered corporate governance. ${ }^{109}$ The new form of benefit corporations falls squarely within this evolving field, as within legal circles it returns to the central issue, as identified by Professor Bodie: "The fundamental question about corporate law is not how to manage the relationships between shareholders, directors, and executives; instead, it is why we have created and sustained corporations in the first place."110 In times of financial insecurity, an increasing income divide, and the shrinking middle class, unbridled corporate emphasis on shareholder profit has been criticized as being a lens that is too narrow, ${ }^{111}$ limiting the ability of business to fully participate in society. ${ }^{112}$ While social entrepreneurship is discussed by some scholars as the way to integrate social good with business, ${ }^{113}$ it is a limited approach, embracing only those entities that form primarily for a public good, and not addressing the larger institutional conception of a corporation within society writ large. A handful of individuals began a campaign to change this paradigm, ${ }^{114}$ eventually creating the benefit corporation, the story of which is an integral part of analyzing the application of CPR Theory and polycentrism to corporate governance.

The genesis of a new corporate law occurred when successful, socially conscious entrepreneurs in the athletic shoe business felt forced to sell their company to the highest bidder, regardless of the changes they knew would be adopted by the new owners to eliminate the company's stakeholder approach. ${ }^{115}$ The movement began with four individuals; three former owners of

${ }^{109}$ Bainbridge, supra note 52, at 549.

${ }^{110}$ Bodie, supra note 51, at 1034.

111 See Janine S. Hiller, The Benefit Corporation and Corporate Social Responsibility, 118 J. BUS. ETHICS 287, 287 (2013) (corporations are viewed as "self-interested and unmindful of their relationship to society.")

112 See Michael R. Deskins, Benefit corporation legislation, version 1.0 - A Breakthrough in Stakeholder Rights, 15 LEWIS \& CLARK L. REV. 1047, 1061 (2011).

${ }^{113}$ See also Brief for 9 Academic Institutions and 27 Comparative Law and Religion Scholars as Amicus Curiae Supporting Respondents, Sebelius v. Hobby Lobby Stores, Inc., 2014 WL 334444, at *34 (2014) (Nos. 13-354); Burwell v. Hobby Lobby Stores, Inc., 134 S. Ct. 2751, 2771 (2014).

114 See @WhartonKnows, B LAB's BART HOULAHAN: BUILDING MORE SOCIALLY RESPONSIBLE CORPORATIONS - KNOWLEDGE@WHARTON KNOWLEDGEWharton B LABS BART HOUlaHAN BuILding MORE SOCIALLY RESPONSIBLE CORPORATIONS COMMENTS (NOV. 7, 2012), http://knowledge.wharton.upenn.edu/article/BLabs-bart-houlahan-buildingmore-socially-responsible-corporations/ (last visited Nov 13, 2016). ${ }^{115} I d$. 
AND1, ${ }^{116}$ and a corporate attorney, William Clark, with extensive experience in drafting corporate and legal entity statutes. ${ }^{117}$ Clark led the drafting of the Model Benefit Corporation Act (Model Act) that they, in turn, promoted in every state legislature across the nation. ${ }^{118}$ The model Act is not a standalone piece of legislation, but is used in coordination with existing entity statutes to stand up the statutory structure of a benefit corporation. ${ }^{119}$

The group also created a non-profit for promoting this legislation and the fundamental shift in corporate perspective it codified, called BLab, ${ }^{120}$ which also provided a vehicle for companies to become certified as BCorps. ${ }^{121}$ BCorps have sometimes been confused with benefit corporations, especially in the popular press, ${ }^{122}$ but they are voluntary associations, not legal entities, and are distinct from the benefit corporation as defined by law. ${ }^{123}$ This Article focuses on the polycentric CPR nature of benefit corporations, not on the voluntary association of BCorps.

Other scholars have described benefit legislation in detail. ${ }^{124}$ For the purposes of this discussion, the primary attributes of a benefit corporation are that: (1) its purpose must include

116 See Susan Adams, Capitalist Monkey Wrench, ForBes (Mar. 25, 2010, 1:20 PM), http://www.forbes.com/forbes/2010/0412/rebuilding-BLabcorporate-citizenship-green-incorporation-mixed-motives.html.

117 See Maryland First State in Union to Pass Benefit Corporation Legislation, CSRWIRE (Apr. 14, 2010, 10:57 AM), http://tinyurl.com/ztmd2sb. ${ }^{118} I d$.

119 See William H. Clark \& Larry Vfanka, The Need And Rationale For The Benefit Corporation: Why It Is The Legal Form That Best Addresses The Needs Of Social Entrepreneurs, Investors, And, Ultimately, The Public (BLab White Paper, 2013), http://benefitcorp.net/sites/default/files/Benefit_Corporation_White_Paper.pdf (stating in $\$ 101(\mathrm{c})$ of the Model Act, found in Appendix A, that "Except as otherwise provided in this [chapter], [the enacting state's business corporation law] shall be generally applicable to all benefit corporations.").

${ }^{120} I d$.

${ }^{121}$ See Benefit Corporation, Model Legislation, http://benefitcorp.net/attorneys/model-legislation (last visited Dec. 12, 2016).

122 See Certified BCorps and Benefit Corporations,

https://www.bcorporation.net/what-are-b-corps/certified-b-corps-and-benefitcorporations (last visited Nov. 14, 2016).

${ }^{123} \mathrm{Id}$.

${ }^{124}$ See generally, Annie Collart, Benefit Corporations: A Corporate Structure to Align Corporate Personhood with Societal Responsibility, 44 Seton Hall L. ReV. 1160, 1176-81 (2014); Michael R. Deskins, Benefit Corporation Legislation, Version 1.0-A Breakthrough in Stakeholder Rights?, 15 LEWIS \& CLARK L. REV. 1047, 1060-70 (2011); Joseph Karl Grant, When Making Money and Making A Sustainable and Societal Difference Collide: Will Benefit Corporations Succeed or Fail?, 46 IND. L. REV. 581, 582-88 (2013); J. Haskell Murray, Choose Your Own Master: Social Enterprise, Certifications, and Benefit Corporation Statutes, 2 AM. U. BuS. L. REV. 1, 1 (2012); Thomas J. White III, Benefit Corporations: Increased Oversight Through Creation of the Benefit Corporation Commission, 41 J. LEGIS. 329, 339-46 (2015). 
either a general or specific public benefit; (2) as part of their fiduciary duties, directors must consider broader stakeholder interests as well as profit; and (3) the entity must assess its performance annually, reporting about the benefits delivered, by using a third party assessment. ${ }^{125}$ Due to the state-based nature of business formation laws, and because the benefit corporation is not part of any model law committee, adoption was unlikely to be an easy task. BLab was formed, in part, to lobby state legislators to adopt benefit corporation legislation. ${ }^{126}$ From the first state Maryland, ${ }^{127}$ that signed benefit corporation legislation into law on April 23, 2010, to the most recent benefit corporation bill as of this writing, Indiana, BLab played a critical role in moving benefit corporation laws in all states that have enacted such legislation, as is shown in Part III. In terms of state-level legislative support, BLab provided testimony for legislative hearings, model legislation, drafting comments, ${ }^{128}$ and pro bono legal service for legislation drafting. ${ }^{129}$ BLab also serves as a catalyst for change by developing and offering a third-party assessment tool for firms to become a certified BCorp. ${ }^{130}$ Yet as is discussed in Part III, BLab and its founders alone could not accomplish the task of legislative adoption; unique considerations emerged and additional partners were needed in each state to support the mission of creating a legal framework for benefit corporations.

In summary, the history of the benefit corporation reflects a handful of individuals who organized for the purpose of changing businesses' relationship with society, using law and legal institutions to formalize the process. It was a bottom-up movement, and it advocated for a vision of the firm that was not too distant from the one that Professor Dodd argued for nearly a century ago, ${ }^{131}$ and not too distinct from the Roman law origins of the firm understood here within the context of CPR Theory and polycentric governance. Further insights may be gained by undertaking a comparative analysis of how two statesConnecticut and Delaware - codified benefit corporation statutes, along with examining their relative success.

${ }^{125}$ See William H. Clark, Jr. \& Elizabeth K. Babson, How Benefit Corporations Are Redefining the Purpose of Business Corporations, 38 WM. MitCHELl L. REV. 818, 838-39 (2012).

${ }^{126}$ See @WhartonKnows, supra note 117.

${ }^{127}$ Brief for Tri Valley Law, PC as Amici Curiae Supporting Petitioners, Conestoga Wood Specialties Corp. v. Sebelius, 2014 WL 491373, at *12-13 (2014) (No. 13-356).

${ }^{128}$ See Model Benefit Corporation Legislation with Explanatory Comments, BENEFITCORP.net (June 24, 2014), http://tinyurl.com/hpd5a3z.

${ }^{129}$ See id.

${ }^{130} \mathrm{Id}$.

${ }^{131}$ See Clark \& Babson, supra note 125 , at 819. 


\section{Case Studies in Benefit Corporation FORMATION}

Building from the groundwork laid in Part I, this Part investigates the experiences of two states - Connecticut and Delaware - in passing benefit corporation statutes. In so doing, this Part aims to offer what some scholars including Professor William Boyd have called for in another context, namely a "more thick description[] of how these forms of governance are taking shape," and to pay more "attention to the connective tissues that bind and hold these forms together." 132

\section{A. Methodology}

A qualitative, comparative case study approach was used to study the enactment of the two benefit corporation laws. ${ }^{133}$ The two case studies were created by first reviewing publicly available documents from each state's legislative databases. ${ }^{134}$ These findings were supplemented through the Westlaw state news database, each state's corporation registration database, ${ }^{135}$ and communication between policymakers. ${ }^{136}$ These data were then

${ }^{132}$ William Boyd, Climate Change, Fragmentation, and the Challenges of Global Environmental Law: Elements of a Post-Copenhagen Assemblage, 32 U. PA. J. INT'L L. 457, 516 (2010).

${ }^{133}$ See Gary King, Robert O. Keohane \& Sidney Verba, DESIGNING SOCIAL INQUIRY: SCIENTIFIC INFERENCE IN QUALITATIVE RESEARCH 1-10 (1994); Bueno de Mesquita, The Benefits of a Social-Scientific Approach to Studying International Affairs, in EXPLAINING INTERNATIONAL RELATIONS SINCE 194549 (Ngaire Woods ed. 1996). These states were chosen given Deleware's central importance in corporate law, and Connecticut's own growing corporate management sector coupled with the relatively more difficult path taken by Connecticut in passing its benefit corporation statute.

${ }^{134}$ See Virginia's Legislative Information System, http://lis.virginia.gov/ (last visited Aug. 17, 2016); Connecticut General Assembly, Bill Information Search, https://www.cga.ct.gov/asp/CGABillInfo/CGABillInfoRequest.asp (last visited Aug. 17, 2016); Delaware State Legislature, Bill Search, http://legis.delaware.gov/legislature.nsf/FSMain?OpenFrameset\&Frame=right\& src=/LIS/lis148.nsf/home (last visited Aug. 16, 2016).

${ }^{135}$ See Virginia State Corporation Commission, Business Entity Search, https://sccefile.scc.virginia.gov/Find/Business (last visited Aug. 17, 2016); Connecticut Secretary of the State, Business Inquiry, http://www.concordsots.ct.gov/CONCORD/online?sn=PublicInquiry\&eid=9740 (last visited Aug. 17, 2016); State of Delaware, Division of Corporations, https://icis.corp.delaware.gov/Ecorp/EntitySearch/NameSearch.aspx (last visited Aug. 17, 2016).

${ }^{136}$ See also E-mail from Richard J. Geisenberger, Chief Deputy Secretary of State, Delaware Department of State to Tanner Wm. Polce, Legislative Aide of Delaware State Senate (Feb. 1, 2016) (on file with author). 
used to analyze: (1) the economic performance of each state including the fastest-growing sectors as context to help discern the state's legislative intent, (2) legislative history as a proxy for studying lobbying efforts, (3) stakeholder advocacy with regards to the level of institutional involvement and professional leadership in advocating for benefit corporations, (4) the number of benefit corporations that were incorporated after the passage of the relevant statute, and (5) local media coverage as a proxy for how engaged civil society was with the passage of each statute.

\section{B. Connecticut}

It is first helpful to understand the context of Connecticut's economic performance, since this became a driver of the benefit corporation debate that happened in the state. On the one hand, the state contributed over $\$ 230$ billion to the U.S. GDP in 2013, ${ }^{137}$ which made Connecticut the second largest economy in the New England area and represented 1.5 percent of the U.S. GDP. ${ }^{138}$ Connecticut's economic data shows that traditional heavy industries were the most recessive sectors from 2013 to 2014. Durable goods, nondurable goods, and construction negatively contributed to Connecticut GDP's percent change in 2013. ${ }^{139}$ Service industries and the management sector were the most important for Connecticut's economic growth ${ }^{140}$; management of companies and enterprises was the second fastest-growing sector. ${ }^{141}$ Thus, services — including corporate management - is increasingly vital to Connecticut's economic vitality, implying that legislators were naturally cautious about making dramatic changes in the state's corporate law.

137 Table 1, Real GDP by State, 2011-2014, available at http://www.bea.gov/newsreleases/regional/gdp_state/2015/xls/gsp0615.xlsx.

138 The largest economy in the New England is Massachusetts, which was responsible for more than 412 billion towards the U.S. GDP from 20132014. See Table 4, Current-Dollar GDP by State, 2011-2014, available at http://www.bea.gov/newsreleases/regional/gdp_state/2015/xls/gsp0615.xlsx.

139 Table 2, Contribution to Percent Change in Real GDP by State, 2013-2014, available at http://www.bea.gov/newsreleases/regional/gdp_state/2015/xls/gsp0615.xlsx (Specifying 21 sectors from Agriculture to Government).

140 Table 2, Contribution to Percent Change in Real GDP by State, 2013-2014, available at http://www.bea.gov/newsreleases/regional/gdp_state/2015/xls/gsp0615.xlsx (Professional and technical services and Management of companies and enterprises contributed $38 \%$ and $29 \%$ to Connecticut GDP's percent change from 2013-2014).

141 See Table 2, Contribution to Percent Change in Real GDP by State, 2013-2014, available at http://www.bea.gov/newsreleases/regional/gdp_state/2015/xls/gsp0615.xlsx. 
But these figures in many ways miss the bigger point. The state of Connecticut was severely impacted by the 2008 financial crisis, ${ }^{142}$ and still in 2014 Connecticut's GDP growth rate was slower than the overall nation. ${ }^{143}$ According to data released by the Bureau of Economic Analysis in June 2015, Connecticut's GDP grew by 0.6 percent from 2013 to 2014, while the country grew 2.2 percent in 2014 after increasing 1.9 percent in 2013. ${ }^{144}$ New York's GDP grew by 2.5 percent, while Massachusetts and New Hampshire both saw GDP growth of 2.3 percent. ${ }^{145}$ These economic statistics informed the debate surrounding what was to become Connecticut's benefit corporation statute.

\section{The History of the Benefit Corporation Legislation Campaign in Connecticut}

In 2014, "Connecticut became the 26th state to give social enterprises - deemed 'benefit corporations' - special designation and the first to allow 'B-Corporations' to maintain their status in the event of ownership's changing hands." 146 The Connecticut Benefit Legislation S.B. 23, "An Act Concerning Benefit Corporations and Encouraging Social Enterprise" ("the Act"), was introduced to the Joint Committee on Commerce on February 7 , 2014, and became effective on October $01,2014 .{ }^{147}$ The campaign for this bill was far from easy. Before the final successful vote on S.B. 23, the supporters of Connecticut benefit corporation legislation failed twice, illustrating the resistance over viewing firms as CPRs, and highlighting the importance of polycentric governance in pushing this issue forward, as is unpacked further in Part IV.

${ }^{142}$ See e.g., Soncia Coleman ET AL., Effects of Foreclosure Crisis in Connecticut, Connecticut General Assembly, Office of Legislative Research Report (Feb. 16, 2010), https://www.cga.ct.gov/2010/rpt/2010-R-0019.htm (the number of Lis pendens fillings were nearly doubled from 2006 to 2009); Rute Pinho, Impact of Financial Crisis on State's Travel and Tourism Industry, Connecticut General Assembly, Office of Legislative Research Report (Jan. 22, 2010), https://www.cga.ct.gov/2010/rpt/2010-R-0011.htm.

${ }^{143}$ Broad Growth Across States in 2014 by Bureau of Economic Analysis, http://tinyurl.com/2nclbd.

${ }^{144}$ See id.

${ }^{145}$ Stephen Busemeyer, Connecticut's GDP Growth Among Slowest In Nation, HARTFORD COURANT (June 10, 2015, 11:32 AM), http://www.courant.com/data-desk/hc-connecticuts-gdp-growth-among-slowestin-nation-20150610-htmlstory.html.

146 Zach Melvin, Nonprofit Gets \$50K Grant Startup Accelerator Program, HARTFORD COURANT, Aug. 12, 2015, 2015 WLNR 23821939.

${ }^{147}$ An Act Concerning Benefit Corporations and Encouraging Social Enterprise, S.B. 23, 2014 Gen. Assemb., Feb. Sess. (Conn. 2014), https://www.cga.ct.gov/asp/cgabillstatus/cgabillstatus.asp?selBillType=Bill\&wh ich_year=2014\&bill_num=23 (last visited Aug. 16, 2016). 
The first Connecticut benefit corporation bill, ${ }^{148}$ H.B. 5490 (Conn. 2012), was introduced on March 8, 2012, however it was not reported out of committee because of the opposition from the Connecticut Bar Association and individual attorneys. ${ }^{149}$ The state bar business law section lodged several reasons for its opposition to the proposed legislation, ${ }^{150}$ related primarily to traditional corporate governance issues of director responsibilities and shareholder rights. It objected to the additional factors beyond shareholder interests that boards of directors were required to consider in their decisions, ${ }^{151}$ the potentially expensive threat and negative impact of benefit enforcement proceedings on boards of directors, and the "burdensome" annual benefit report. ${ }^{152}$ However, the bar committee supported the general concept of benefit corporations, and offered to work with legislators to produce an acceptable statute. ${ }^{153}$

The Benefit Corporation bill was reintroduced to the Connecticut General Assembly again on February 7, 2013, ${ }^{154}$ but it failed for the second straight year. ${ }^{155}$ There was no public opposition to the bill this time, however. Rather, "time ran out for a vote in the state Senate," 156 implying the lack of priority. The

${ }^{148}$ An Act Concerning the Establishment of Benefit Corporations, H.B. 5490, 2012 Gen. Assemb., Feb. Sess. (Conn. 2012), https:/www.cga.ct.gov/asp/cgabillstatus/cgabillstatus.asp?selBillType=Bill\&wh ich_year=2012\&bill_num=5490.

${ }^{149}$ See An Act Concerning the Establishment of Benefit Corporations: Hearing on H.B. 5490 Before the Judiciary Comm., 2012 Gen. Assemb., Feb. Sess. (Conn. 2012) (statement of John M. Lawrence, Vice Chair of the Business Law Section, Connecticut Bar Association); An Act Concerning the Establishment of Benefit Corporations: Hearing on H.B. 5490 Before the Judiciary Comm., 2012 Gen. Assemb., Feb. Sess. (Conn. 2012).

${ }^{150}$ See Lawrence, supra note 149.

${ }^{151} \mathrm{Id}$.

${ }^{152} I d$.

${ }^{153}$ Id.; Mark Loewenstein \& Herrick Lidstone, Benefit Corporations in Colorado, Bus. L. NewsLETTER (Jan. 2013), http://www.leg.state.co.us/CLICS/CLICS2013A/commsumm.nsf/b4a3962433b5 2fa787256e5f00670a71/f3331123c7c0d03487257b12007130e7/\$FILE/130214 \%20AttachB.pdf (with the support of the Colorado Bar Association, a number of attorneys opposed the strict mandates and marketing aspects of the proposed legislation in 2011 and 2012); Benefit Corporations: Hearing on H.B. 2650 Before the Commerce Comm., Kan. Leg., (Kan. 2012) (statement of Joseph Molina, Kansas Bar Association), http://kslegislature.org/li_2014/b2013_14/committees/ctte_h_cmrce_lbr_1/docu ments/testimony/20140221_10.pdf.

${ }^{154}$ H.B. 6356, 2013 Gen. Assemb., Jan. Sess. (Conn. 2013), https://www.cga.ct.gov/2013/FC/pdf/2013HB-06356-R000839-FC.pdf. 155 See Dan Harr, B is for Benefit: Bill on Track to Ease Legalities for Commerce Aimed at Public Good, Hartford Courant, Jan. 15, 2014, available at 2014 WLNR 1386354. ${ }^{156}$ Id. 
bill was put on the fast track the following year, paving the way for the passage of S.B. 23 in 2014. ${ }^{157}$ S.B. 23 was introduced by Sen. Donald E. Williams, Sen. Martin M. Looney, Rep. J. Brendan Sharkey, and Rep. Joe Aresimowicz, and was co-sponsored by fifteen representatives and nine senators. ${ }^{158}$ On March 11, 2014, the Connecticut Commerce Committee unanimously passed the bill. ${ }^{159}$ It received thirty-four to four votes in the Connecticut Judiciary Committee on April 1, 2014, ${ }^{160}$ and secured the backing of forty-five out of forty-eight voters in Connecticut Appropriations Committee on April 24, 2014. ${ }^{161}$

S.B. 23 included several amendments to earlier proposals. First, the new bill followed the Model Act by including a "Benefit Director" and a "Benefit Officer" with specific powers, duties, rights and immunities, ${ }^{162}$ which are separate from the regular directors and officers. ${ }^{163}$ These new designations can lessen the impact on general directors and therefore addressed one of the concerns stated by the Vice Chair of the Business Law Section of Connecticut Bar Association that the dual interests would be too burdensome. ${ }^{164}$ Second, S.B. 23 narrowed and specified the terms of the benefit enforcement proceeding so that only certain groups of directors or shareholders could bring a derivative action; this amendment answered another concern by the state bar association that the right to bring an enforcement proceeding was too tenuous. ${ }^{165}$ In fact, the benefit director, benefit officer, and the limited right to bring a benefit enforcement proceeding, are all in the Model Act. ${ }^{166}$ Third, the final bill added an appraisal right clause as a protection for the minority shareholders who opposed the conversion to a benefit corporation, ${ }^{167}$ which was missing in

\footnotetext{
${ }^{157}$ Id.

${ }^{158}$ An Act Concerning Benefit Corporations and Encouraging Social Enterprise, S.B. 23, 2014 Gen. Assemb., Feb. Sess. (Conn. 2014), available at https://www.cga.ct.gov/asp/cgabillstatus/cgabillstatus.asp?selBillType=Bill\&wh ich_year=2014\&bill_num=23 (last visited Aug. 16, 2016).

${ }^{159}$ Commerce Comm. Vote Tally Sheet, 2014 Gen. Assemb. Sess. (Conn. 2014), https://www.cga.ct.gov/2014/TS/s/pdf/2014SB-00023-R00CECV2-TS.pdf.

${ }^{160} I d$.

${ }^{161}$ Appropriations Comm. Vote Tally Sheet, 2014 Gen. Assemb. See. (Conn. 2014), https://www.cga.ct.gov/2014/TS/s/pdf/2014SB-00023-R00APPCV86-TS.pdf.

${ }^{162}$ S.B. 23 , supra note 158 , at $§ 10, \S 12$.

${ }^{163}$ See id. at $\$ 9 \& \$ 11$.

${ }^{164}$ See Lawrence, supra note 149

165 See S.B. 23, supra note 158 , at $§ 13(\mathrm{c}), \S 10(\mathrm{~b}), \S 12$.

${ }^{166}$ See Lawrence, supra note 149 ("[T]benefit enforcement proceeding . . . may even be brought by a director who has no financial interest in the corporation."); S.B. $23, \S 10, \S 12$, supra note 158 , at $\$ 16$.

167 See the Model Act, supra note 121, Appendix A, $\$ 302$ (Benefit Director), $§ 304$ (Benefit Officer \& $\$ 305$ (Right of Action).
} 
the original bill and was also mentioned in a local bar association's opposing testimony. ${ }^{168}$ Aside from the above-mentioned key amendments, S.B. 23 implemented a more flexible approach with respect to the annual benefit report to satisfy the demand from the local bar association. ${ }^{169}$

\section{Stakeholder Advocacy for the Connecticut Benefit Corporation Legislation}

All told, twenty-three organizations and individuals gave testimony before the Connecticut Commerce Committee in support of the Act. Nearly all of the supporters of the legislation believed that passage of this Act would spur Connecticut's economy and create more job opportunities. ${ }^{170}$ Leslie Krumholz, the founder of GoodStreets, an online consumer review site of local businesses, stated "a bill like S.B. 23 can provide exactly what we need to create thriving businesses that will not only produce profits and create more jobs but will also provide a lasting impact to our state in the form of a general public benefit." ${ }^{171}$ In the midst of a slow

${ }^{168}$ See Lawrence, supra note 149 ("[A] regular corporation could be converted to a benefit corporation by vote of two-thirds of the shareholders without any form of protection ... for the minority shareholders who oppose such a change.").

${ }^{169}$ According S.B. 23, the disclosure of the information regarding director's compensation and any financial, confidential, or proprietary information in the benefit report is optional. However, the omission of such information requires permission from the third-party standard adopted by the benefit corporation in H.B. 5490. Compare S.B. 23, §10, §12, supra note 158, at $\S 15(\mathrm{~b}-\mathrm{c})$ with $\S 11(\mathrm{c})$.

${ }^{170}$ See An Act Concerning Benefit Corporations and Encouraging Social Enterprise: Hearing on S.B. 23 Before the Commerce Comm., 2014 Gen. Assemb., Feb. Sess. (Conn. 2014) (statement of Kate Emery, Chief Executive Officer, The Walker Group) (the Act will provide an easy, inexpensive way for other business to set up as a social enterprise and thereby create jobs), https://www.cga.ct.gov/2014/CEdata/Tmy/2014SB-00023-R000227-

Kate\%20Emery,\%20CEO,\%20The\%20Walker\%20Group-TMY.PDF. See also An Act Concerning Benefit Corporations and Encouraging Social Enterprise: Hearing on S.B. 23 Before the Commerce Comm., 2014 Gen. Assemb., Feb. Sess. (Conn. 2014) (statement of Jeff Shaw, Director of Public Policy, Connecticut Association of Nonprofits) ("This proposal will provide new opportunities to address service needs and drive economic growth by bringing new jobs to Connecticut and making our state an attractive home for forwardthinking individuals, policymakers, and companies"), https://www.cga.ct.gov/2014/CEdata/Tmy/2014SB-00023-R000227Jeff\%20Shaw, \%20Director\%20of\%20Public\%20Policy, \%20CT\%20NonprofitsTMY.PDF.

${ }^{171}$ An Act Concerning Benefit Corporations and Encouraging Social Enterprise: Hearing on S.B. 23 Before the Commerce Comm., 2014 Gen. Assemb., Feb. Sess. (Conn. 2014) (statement of Leslie Krumholz, co-founder, GoodStreets), https://www.cga.ct.gov/2014/CEdata/Tmy/2014SB-00023- 
recovery from a severe economic downturn, it seems that there was a re-thinking of the relationship between business and society toward a potentially more CPR mindset.

Despite the pressure to spur economic growth and job opportunities, it was a non profit organized to promote social entrepreneurship, reSET, who provided leadership to the three years' long Connecticut movement was critical to pass the state's benefit corporation bill. ${ }^{172}$ reSET generally provides resources and incubator offices for social enterprises, like A Happy Life, ${ }^{173}$ in their Hartford Connecticut office. ${ }^{174}$ But more specifically, reSET worked to gain the Connecticut Governor's support for the benefit corporation legislation after it failed for the second straight year. ${ }^{175}$ The motivation behind reSET's tireless efforts to promote the bill echoed the state's need for job opportunities; Kate Emery, ${ }^{176}$ the founder of reSET and "godmother" of Connecticut social enterprise movement, pointed out that the passage of benefit corporation legislation could attract "serious social entrepreneurs to Hartford." 177

The vision for the benefit corporation to support social enterprises was shared by other stakeholders. The American Association of Retired Persons (AARP)-Connecticut, for example, expressed support for the benefit corporation legislation because it saw opportunities for social enterprises to become benefit corporations, and therefore to be a valuable opportunity for "Encore Entrepreneurs," 178 people over 50 years old who seek

R000227-Leslie\%20Krumholz,\%20Co-Founder,\%20GoodStreets-TMY.PDF [emphasis added].

${ }^{172}$ See Dan Haar, Reset Celebrates Legislative Win Hartford, HARTFORD COURANT (May 10, 2014), 2014 WLNR 12750158 ("The organization successfully lobbied for the legislation's passage after three years of trying.").

${ }^{173}$ See Dan Harr, B is for Benefit: Bill on Track to Ease Legalities for Commerce Aimed at Public Good, HARTFORD COURANT, Jan. 15, 2014, 2014 WLNR 1386354.

${ }^{174}$ See Haar, supra note 172.

175 See Harr, supra note 173 ("Gov. Dannel P. Malloy showed up at reSET's Pratt Street office Tuesday to deliver his support.").

${ }^{176}$ Christine Stuart, 20 Connecticut Social Entrepreneurs Convert Their Companies to Benefit Corporations, CTNEWSJUNKIE.COM (Oct. 1, 2014, 2:50 PM), http://www.ctnewsjunkie.com/archives/entry/social_entrepreneurs_celebrate_ne w_corporate_structure/.

${ }^{177}$ Haar, supra note 172.

${ }^{178}$ See An Act Concerning Benefit Corporations and Encouraging Social Enterprise: Hearing on S.B. 23 Before the Commerce Comm., 2014 Gen. Assemb., Feb. Sess. (Conn. 2014) (statement of Robert Romasco, President, American Association of Retired Persons Connecticut), https://www.cga.ct.gov/2014/CEdata/Tmy/2014SB-00023-R000227-AARPTMY.PDF. 
meaningful second careers. ${ }^{179}$ In addition to the AARP, the Connecticut Veterans' Chamber of Commerce supported the bill; it believed that the option of a benefit corporation would attract entrepreneurial veterans to the state given the propensity of veterans to have a strong "sense of service," and the opportunities for social enterprises to prosper under this form of business. ${ }^{180}$

The social enterprise, as was discussed in Part II, can be defined in various ways, and it is in the confluence between social good and business profit where benefit corporations found strong support in Connecticut. An information technology company $\mathrm{CEO}$, for example, described the difficult time that the for-profit company had when it tried to choose a legal form that would support the founders' intent to both earn a profit and "make a positive social impact." 181 It was forced "to spend tens of thousands of dollars in legal fees and time creating a complex legal structure" 182 to accomplish the same result as compared to the "easy inexpensive way" in which the benefit corporation accomplished the same result. ${ }^{183}$ This same calculus may have informed the decision-making of a variety of firms considering whether to make the switch from traditional corporate forms to benefit corporations.

\title{
3. Local Impact of Benefit Corporation Legislation
}

Twenty companies immediately instituted the legal change to become a benefit corporation when the legislation became effective. ${ }^{184}$ Subsequently, reSET, the main supporter ${ }^{185}$ behind Connecticut's Benefit Corporation legislation discussed above, ${ }^{186}$ was awarded $\$ 50,000$ by the U.S. Small Business Administration

\author{
${ }^{179}$ See id. \\ ${ }^{180}$ See An Act Concerning Benefit Corporations and Encouraging
} Social Enterprise: Hearing on S.B. 23 Before the Commerce Comm., 2014 Gen. Assemb., Feb. Sess. (Conn. 2014) (statement of Dawn McDaniel, Executive Vice President, Connecticut Veterans Chamber of Commerce) (arguing that social enterprise would increase opportunity and options for veteran business ownership), https://www.cga.ct.gov/2014/CEdata/Tmy/2014SB-00023R000227-

Dawn\%20McDaniel,\%20CT\%20Veterans\%20Chamber\%20of\%20CommerceTMY.PDF.

${ }^{181}$ Emery, supra note 170.

${ }^{182} \mathrm{Id}$.

${ }^{183} \mathrm{Id}$.

${ }^{184}$ See Christine Stuart, 20 Connecticut Social Entrepreneurs Convert Their Companies to Benefit Corporations, CTNEWSJUNKIE.COM (Oct. 1, 2014, 2:50 PM), http://www.ctnewsjunkie.com/archives/entry/social_entrepreneurs_celebrate_ne w_corporate_structure/.

${ }^{185}$ Id.

${ }^{186} I d$. 
to use its startup accelerator program exclusively to help social entrepreneurs - including benefit corporations in their formation stage - by providing "access to expert advisers, mentors and funding sources, as well as reSET's job board and internship platform." 187

According to B-Lab ${ }^{188}$ and the Connecticut Secretary of the State's Business databases, ${ }^{189}$ there were thirty-nine active benefit corporations in Connecticut as of August, 2016. ${ }^{190}$ Twenty-seven Connecticut corporations filed benefit corporation registration/conversion papers in 2014, and another sixteen corporations filed in 2015. ${ }^{191}$ Among those forty-three benefit corporations, however, four companies were dissolved by mid2016. ${ }^{192}$

Connecticut media interests in the Benefit Corporation legislation mimics state legislative actions. From May 18, 2013 to August 12, 2015, there were a total of twenty-two articles covered the phrase "Benefit Corporation" that had been published in leading local newspapers such as Hartford Courant, Connecticut Post, and Herald (New Britain, CT). However, there were no reports about the Benefit Corporation in any Connecticut news when absent legislative action. Similarly, there are only three articles about the term Benefit Corporation that were published in local newspapers three months after Connecticut's benefit corporation legislation came into effect on October 1, 2014, as shown in Figure 2.

187 See Zach Melvin, Nonprofit Gets \$50K Grant Startup Accelerator Program, HARTFORD COURANT (Aug. 12, 2015), http://digitaledition.courant.com/tribune/article_popover.aspx?guid=db6e3adcc11e-4f6d-99f1-73c90e4a48e3\#sthash.UPWYJ79F.dpuf.

${ }^{188} \mathrm{~B}$ Lab makes its "best effort to create an accurate accounting of benefit corps and is inclusive of all data collated by B Lab from state agency reports. Many states do not currently track the names or number of benefit corporations. B Lab continuously collects this data, however each state has different level of reporting capabilities." Find a Benefit Corp, benefitcorp.net, http://benefitcorp.net/businesses/find-a-benefitcorp?field_bcorp_certified_value $=\&$ state $=$ Connecticut $\&$ title $=\& o p=$ Go\&sort_by =title\&sort_order=DESC (last visited Jan. 24, 2016).

${ }^{189}$ Connecticut Sec'y of St., http://www.concordsots.ct.gov/CONCORD/online?sn=PublicInquiry\&eid=9740 (last visited Jan. 24, 2016).

${ }^{190}$ See Find a Benefit Corp, benefitcorp.net, http://benefitcorp.net/businesses/find-a-benefitcorp?field_bcorp_certified_value $=\&$ state $=$ Connecticut $\&$ title $=\& o p=$ Go $\&$ sort_by =field_bcorp_state_value\&sort_order=ASC (last visited Jan. 24, 2016).

${ }^{191}$ Connecticut Secretary of the State Business search database does not allow searches by entity type. We gathered a list of benefit corporations that converted or incorporated in Connecticut on B Lab's website, which were then cross-referenced with the BLab list and Connecticut Secretary of the State Business search database.

${ }^{192}$ See id. 


\section{Figure 2: Number OF MEDIA ARTICles ReFERENCING BENEFIT CORPORATION IN CONNECTICUT, JANUARY 2013-JANUARY 2016 $^{193}$}

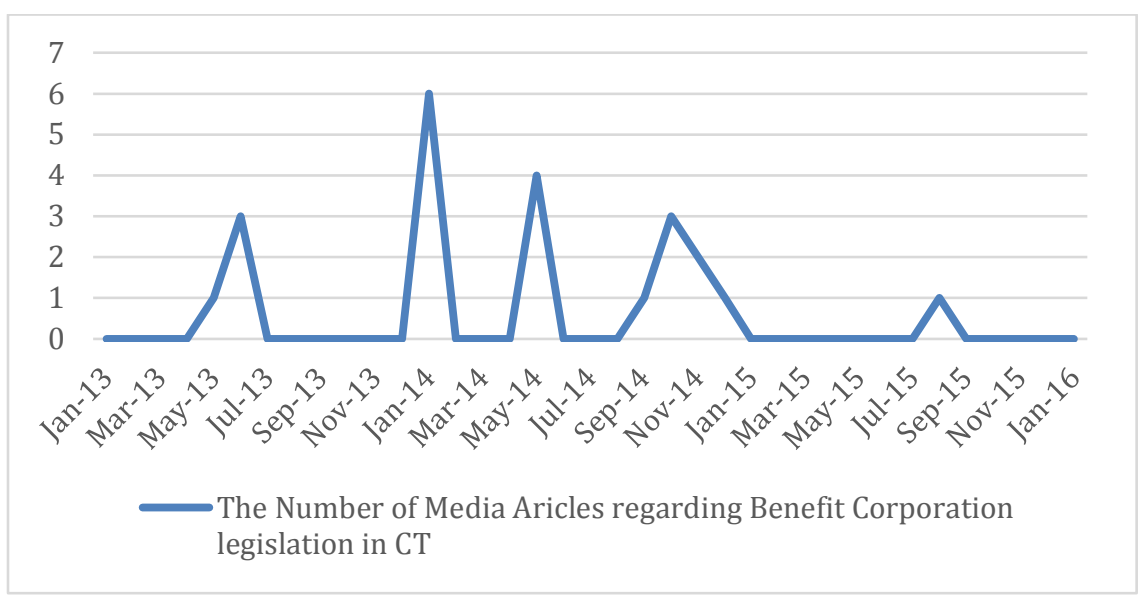

As is apparent in Figure 2, when H.B. 6356, the second benefit corporation bill, ${ }^{194}$ was introduced in February 2013, media attention hit its first peak. Then S.B. 23 was offered in January 2014, passed the House and Senate in March and April respectively, ${ }^{195}$ and became effective in October 2014, after which time media attention declined. These data highlight the extent to which the public was engaged at various points in the passage of Connecticut's benefit corporation legislation, which we hypothesize may be correlated with higher degrees of uptake as is discussed further in Part III.

\section{Delaware}

According to data released by the Bureau of Economic Analysis, ${ }^{196}$ Delaware's GDP growth rate was 1.2 percent from 2013-14. ${ }^{197}$ The state contributed more than $\$ 56$ billion to U.S. GDP in 2014, which made Delaware the smallest economy in the Northeast. ${ }^{198}$ But despite its relatively small economy, Delaware is

193 This chart is based on Westlaw "Connecticut News" database. The research covered the phrase "benefit corporation" from January 2013 to January 2016.

194 The first BC bill, H.B. 5490, was not reported out of the committee. That may explain why there was no media article about this bill in 2012. See supra note 150and accompanying text.

196 Broad Growth Across States in 2014, BUREAU OF ECON. ANALYSIS (June 10, 2015), http://www.bea.gov/newsreleases/regional/gdp_state/gsp_newsrelease.htm.

197 Table 1, Real GDP by State, 2011-2014, BUREAU OF ECON. ANALYSIS, available at http://www.bea.gov/newsreleases/regional/gdp_state/2015/xls/gsp0615.xlsx. ${ }^{198} I d$. 
remarkable because it serves as the place of incorporation for "more than 50 percent of all U.S. publicly-traded companies and 63 percent of the Fortune 500." 199 In 2013, approximately eightyfive percent of U.S. Initial Public Offerings (IPOs) involved Delaware corporations. ${ }^{200}$ It is beyond dispute that Delaware is the most significant U.S. state regarding corporate law, ${ }^{201}$ and Delaware corporate statutes have tremendous influence among institutional investors, corporate managers, and the financial intermediaries who raise capital. ${ }^{202}$ Therefore, the story of Delaware's benefit corporation legislation can serve as an important data point for other U.S. states and foreign nations considering similar steps.

\section{The History of Benefit Corporation Legislation Campaign in Delaware}

On July 17, 2013, Delaware became the nineteenth state to pass a statute recognizing the benefit corporation as a legal entity. ${ }^{203}$ Senate Bill 47 of the 147th General Assembly, "An Act to Amend Title 8 of the Delaware Code Relating to the General Corporation Law," was introduced to the Delaware Senate Small Business Committee on April 18, 2013, passed by the Delaware House of Representatives on June 13, 2013, and signed into law by

${ }^{199}$ Matthew W. Bower, When it Comes to Incorporating Your Startup, Why Delaware?!? NAT'L L. REV. (Feb. 11, 2015),

http://www.natlawreview.com/article/when-it-comes-to-incorporating-yourstartup-why-delaware.

${ }^{200}$ Jeffrey R. Wolters, Delaware Law Pitfalls in IPOs, Bus. L. TODAY (2013),

http://www.americanbar.org/publications/blt/2013/11/delaware_insider.html.

${ }^{201}$ See e.g., Alicia E. Plerhoples, Delaware Public Benefit Corporations 90 Days Out: Who's Opting In?, 14 U.C. DAVIS BuS. L. J. 247, 248-49 (2014); Omari Scott Simmons, Branding the Small Wonder: Delaware's Dominance and the Market for Corporate Law, 42 U. RICH L. REV. 1129, 1129 n.3 (2008); William J. Carney, George G. Shepherd, Joanna Shepherd Bailey, Lawyers, Ignorance, and the Dominance of Delaware Corporate Law, 2 HARV. BUS. L. REV. 123, 125 (2012).

202 Brian J. Broughman, Jesse M. Fried, \& Darian Ibrahim, Delaware Law as Lingua Franca: Evidence from VC-backed Startups (Harv. John M. Olin Center for Law, Econ., \& Bus., Discussion Paper No. 721, 2012),

http://www.law.harvard.edu/programs/olin_center/papers/pdf/Fried_et\%20al_72 1.pdf (last visited July 4, 2016) ("[F]irms wishing to sell their shares to mostly out-of-state public investors through an IPO may also choose Delaware law in part to provide a common language to their shareholders"); Steven Lipin, Firms Incorporated in Delaware Are Valued More By Investors, WALL ST. J. (Feb. 28, 2000); Table 2, Contribution to Percent Change in Real GDP by State, 2013 2014, BUREAU OF ECON. ANALYSIS, http://www.bea.gov/newsreleases/regional/gdp_state/2015/xls/gsp0615.xlsx.

${ }^{203}$ S.B. 47, 147th Gen. Assemb. (Del. 2013), http://www.legis.delaware.gov/LIS/LIS147.NSF/vwLegislation/SB+47. 
Governor Jack Markell on July 17, 2013. ${ }^{204}$ The primary sponsor of this bill was Democratic Senator David Sokola, and the bill was co-sponsored by three senators and six representatives. ${ }^{205}$ As is apparent, S.B. 47 passed quickly and was unanimously supported by legislators in both the House and Senate; indeed, it received twenty positive votes of the twenty-one potential votes in Delaware State Senate. ${ }^{206}$ The House Committee Report stated that the bill passed with such overwhelming support because the Economic Development, Banking, Insurance, and Commerce Committee found that the creation of public benefit corporation might incentivize new corporations to form in Delaware. ${ }^{207}$ However, the statutory history tells only one part of the story. As described further in Part III(C)(2), there was extended debate about the wisdom of the benefit corporation.

Unlike any other state to pass a benefit corporation law, Delaware's version was the first to vary significantly from the Model Benefit Corporation Legislation created by B-Lab. ${ }^{208}$ Although portions were subsequently deleted or amended, Delaware's first benefit corporation law included four variations. First, Delaware corporations were required to state that they were public benefit corporations in their certificates of incorporation, ${ }^{209}$ and the name of the company was required to contain either "public benefit corporation," "PBC," or "P.B.C."210 Second, Delaware PBCs were required to state a specific public benefit, defined as "a positive effect (or reduction of negative effects) on one or more categories of persons, entities, communities or interests (other than stockholders in their capacities as stockholders)." ${ }^{211}$ The Model Legislation makes the disclosure of the specific public benefit purpose optional, compared to the

${ }^{204}$ Id.

${ }^{205}$ Id. (Sens. Henry, Lavelle, Townsend; Reps. M. Smith, Walker, Baumbach, Q. Johnson, Bennett, Peterman).

${ }^{206} I d$. (twenty Yes and one Not voting).

${ }^{207}$ House of Representative Committee Report on S.B. 47, 147th Gen. Assemb. (Del. 2013), http://www.legis.delaware.gov/LIS/LIS147.NSF/d81 ce478bd9ae572852568730 079e2fe/77b93d79f298752d85257b6c006f2ec7?OpenDocument (last visited June 11, 2016).

${ }^{208}$ Model Legislation, supra note 121.

${ }^{209}$ S.B. 47, supra note 203, at §362(a) \& (c).

${ }^{210}$ Steven H. Schulman \& Terry Enright, Delaware Public Benefit Corporations: A Brief Introduction, AG DEAL DIARY (Nov. 13, 2013), https://www.akingump.com/en/experience/practices/corporate/ag-dealdiary/delaware-public-benefit-corporations-a-brief-introduction.html.

${ }^{211}$ S.B. 47, supra note 203, at $\$ 362$ (b) (including, but not limited to, effects of an artistic, charitable, cultural, economic, educational, environmental, literary, medical, religious, scientific or technological nature). 
required general public benefit. ${ }^{212}$ Third, Delaware's PBC statute set a very high shareholder approval vote requirement as compared to than Model Law;" 213 ninety percent of the outstanding shares of each class of stock of an existing corporation are required to convert into a Delaware PBC, ${ }^{214}$ whereas under the Model Law only two-thirds is required. ${ }^{215}$ Lastly, unlike the Model Law's requirement of an annual assessment by a third party standard, to determine the extent to which a company successfully created and implemented a specific public benefit, ${ }^{216}$ the Delaware PBC statute requires only a biannual statement to be given to stockholders with a third party standard being optional. ${ }^{217}$

As was quickly noted however, "publicly traded entities, even those with clear identifiable benefits to the public, may find the 90 percent stockholder approval threshold too high a bar." 218 In order to accommodate the need for more reasonable restrictions for a corporation to become a PBC, ${ }^{219}$ the Corporation Law Council of the Delaware State Bar Association announced proposed amendments to the Delaware General Corporation Law on April 2, 2015. ${ }^{220}$ Those amendments were a part of Senate Bill $75,{ }^{221}$ which was passed by the Senate unanimously and received forty positive of the forty-one votes in the House on June 11,

${ }^{212}$ Model Legislation, supra note 121, at §201(b) (“The articles of incorporation of a benefit corporation may identify one or more specific public benefits that it is the purpose of the benefit corporation to create in addition to its purpose under subsection(a) (\$201(a) general public benefit purpose)").

${ }^{213}$ Steven H. Schulman \& Terry Enright, Delaware Public Benefit

Corporations: A Brief Introduction, AG DEAL DIARY (Nov. 13, 2013),

https://www.akingump.com/en/experience/practices/corporate/ag-dealdiary/delaware-public-benefit-corporations-a-brief-introduction.html.

${ }^{214}$ S.B. 47 , supra note 203 , at $\$ 363$.

${ }^{215}$ See Model Legislation, supra note 121, at §104(a) (“An existing

business corporation may become a benefit corporation under this . . . in order to be effective, the amendment must be adopted by at least the minimum status vote").

${ }^{216} I d$. at $\$ 401$.

${ }^{217}$ S.B. 47 , supra note 203 , at $\$ 366$.

${ }^{218}$ Steven H. Schulman \& Terry Enright, Delaware Public Benefit

Corporations: A Brief Introduction, AG DEAL DIARY (Nov. 13, 2013), https://www.akingump.com/en/experience/practices/corporate/ag-dealdiary/delaware-public-benefit-corporations-a-brief-introduction.html.

${ }^{219}$ Gregory P. Williams, Amendments to the DGCL, Harvard Law School Forum on Corporate Governance and Financial Regulation (June 30, 2015), https://corpgov.law.harvard.edu/2015/06/30/amendments-to-the-dgcl/.

${ }^{220}$ Frederick H. Alexander, Amendments to the DGCL Remove Obstacles to Adoption of Public Benefit Status, BloOMBERG News (May 1, 2015), http://www.bna.com/amendments-dgcl-remove-n17179926022/.

${ }^{221}$ S.B. 75, 148th Gen. Assemb. (Del. 2015), available at http://legis.delaware.gov/legislature.nsf/FSMain?OpenFrameset\&Frame=right\& src=/LIS/lis 148.nsf/home (last visited July 3, 2016). 
2015. ${ }^{222}$ Senate Bill 75 was signed into law by Governor Markell on June $24,2015,{ }^{223}$ making several important changes to provisions of the Delaware PBC statute that hindered implementation. ${ }^{224}$ First, the original approval requirement of a ninety percent vote of all outstanding shares on an existing company to become a PBC was amended to two-thirds of all outstanding shares entitled to vote. ${ }^{225}$ Second, the mandatory naming requirement was made optional. ${ }^{226}$ S.B. 75 also added a "market out exception to the appraisal rights provided in Section 363(b), which is available to a stockholder of a corporation that merges or converts into a public benefit corporation." 227 The new market out exception for Delaware PBCs is similar to the exception that applies to appraisal rights generally under $\S 262 .{ }^{228}$ Under the 2015 amendments, the appraisal rights are not absolute when a corporation coverts to a PBC..$^{229}$

Unlike the 2013 PBC statute, neither the Senate nor the House stated the purpose of the amendments to the PBC statute in their Committee Reports. ${ }^{230}$ From the plain text of the relevant sections in this bill, the amendments appear to try to make entrepreneurs and investors more comfortable to incorporate as or covert their companies into PBCs. ${ }^{231}$ Although the structure of PBC statute remained largely intact, both public and private corporations should have a clearer path to conversion. ${ }^{232}$

\section{Stakeholder Advocacy for Delaware Benefit Corporation Legislation}

The Delaware discussion of proposed benefit corporation legislation began in 2009. ${ }^{233}$ At that time, there were concerns about the innovative legal designation among many key players, such as Frederick Alexander, the chair of the Delaware Bar's

${ }^{222} I d$.

${ }^{223} I d$.

${ }^{224}$ See Alexander, supra note 220.

${ }^{225}$ S.B. 75 , supra note 221 , at $\$ 12$.

${ }^{226}$ See id. at $\$ 11$.

227 John Marsalek, 2015 Amendments to the Delaware General Corporation Law (June 29, 2015), http://tinyurl.com/gqhq24w.

${ }^{228}$ Williams, supra note 219.

${ }^{229} \mathrm{Id}$.

${ }^{230}$ The House of Representatives only mentioned that this bill was meant to prevent corporations from adopting bylaws that would force the loser of a stakeholder lawsuit to pay the corporate legal fees. See House of Representative Committee Report on S.B. 75, 148th Gen. Assemb., §§ 2-3 (Del. 2015), http://tinyurl.com/ho4w473 (last visited July 4, 2016).

${ }^{231}$ Alexander, supra note 220.

${ }^{232} I d$.

${ }^{233}$ Katie Gilbert, Delaware Overcomes its Qualms and Advances B

Corps Law, InSTITUTIONAL INVESTOR (June 14, 2013), 2013 WLNR 15844875. 
Corporations Law Council. ${ }^{234}$ One key argument was that an investor would not want to invest in a company that did not consider serving shareholders to be its primary purpose. ${ }^{235}$ In September 2012, B-Lab organized a meeting at which twelve benefit corporation executives and several of their investors spoke with the Delaware Secretary of State Jeffrey Bullock, along with the Chancellor of the Court of Chancery Leo Strine, and dozens of attorneys in the Delaware Bar's Corporations Law Council. ${ }^{236}$ This meeting was critical to the advocacy efforts since the underlying philosophy of Delaware corporate law "is to enable managers and investors to order their internal financial affairs in ways that make sense to them." 237 The meeting provided a channel for information exchange between advocates and corporate investors. As a result, lawmakers were more aware that public firms and institutional investors, such as Facebook and Union Square Ventures, ${ }^{238}$ cared about their social missions, perhaps even more than their stock prices, and made investments with "an eye toward their social missions."239

In addition to B-Lab's coordination and professional leadership, Chief Justice Strine provided support by promoting this new corporate form in several law review articles. ${ }^{240}$ Specifically, Chief Justice Strine argued for Delaware PBC primacy for directors and officers who wish to do good for stockholders, society, and the environment, ${ }^{241}$ by responding to opponents ${ }^{242}$ such as Charles Elson who argued that this legislation did not make sense owing to the fact that investors would lose recourse. ${ }^{243}$ As a true believer in the benefit corporation movement, and owing

${ }^{234}$ See id.

${ }^{235}$ See id.

${ }^{236}$ See id.

${ }^{237}$ See id.

${ }^{238}$ CEO Mark Zuckerberg echoed the thinking behind the benefitcorporation model in a letter to prospective shareholders before Facebook's IPO. See id.

${ }^{239}$ See id.

${ }^{240}$ Strine, Do the Right Thing, supra note 16, at 235; Leo E. Strine Jr., The Dangers of Denial: The Need for a Clear-Eyed Understanding of the Power and Accountability Structure Established by the Delaware General Corporation Law, WAKE FOREST L. REV. (forthcoming 2016).

241 John Montgomery, Why Does the Delaware Public Benefit

Corporation Matter to Silicon Valley? Greatfromthestart.com (July 9, 2015), http://www.greatfromthestart.com/why-does-the-delaware-public-benefitcorporation-matter-to-silicon-valley/ (last visited July 5, 2016).

${ }^{242}$ Strine, Do the Right Thing, supra note 16, at 244 ("the Delaware statute also creates incentives for the creation of objectives and standards that allow for directors to be held accountable for managing the corporation in a sustainable and responsible manner.").

243 See Public Benefits Firms Mulled, News J. (Wilmington, Del.) (Apr. 21, 2013), 2013 WLNR 9782796. 
to his role as Chief Justice of one of the most influential business courts in the world, ${ }^{244}$ Strine's support was pivotal for Delaware's PBC statute.

The advocacy undergirding the Delaware campaign was distinct from the situation in Connecticut. The Delaware State administration's backing for PBC legislation and their active advocacy were indispensable in its eventual passage. On the other hand, the Governor and the Secretary of State did not initiate the campaign and remained unconvinced that their state was ready for this legal designation at the beginning of the advocacy, until the meeting organized by B-Lab. ${ }^{245}$ According to the statements from the Delaware Governor's office, ${ }^{246}$ the commitment to be the leader in U.S. corporate law and the peer pressure from nearly half of the states who already adopted benefit-corporation legislation were the driving forces behind the office's enthusiasm for Delaware PBC advocacy. ${ }^{247}$

In summary, the unanimous passage of the Delaware PBC statute, and its subsequent amendments, were ultimately the result of collaborative efforts of Delaware Governor Markell, the Delaware State Bar Association, the Delaware Court of Chancery, the Secretary of State, B-Lab, and grassroots supporters. Among all those stakeholders, B-Lab's professional leadership and experiences in benefit corporation advocacy across other states played a crucial role in the success of the advocacy efforts for the Delaware PBC.

\section{Local Impact of Benefit Corporation Legislation}

As of December 31, 2015, 460 PBCs have been formed in Delaware, of which 404 were newly formed entities. ${ }^{248}$ Among the

${ }^{244}$ See id.; Leo E. Strine, Jr., The Dangers of Denial: The Need for a Clear-Eyed Understanding of the Power and Accountability Structure Established by the Delaware General Corporation Law (Research Paper No. 15$08,40)$ (" $[S]$ tatutes should be adopted giving those constituencies enforceable rights that they can wield. The benefit corporation is a modest, but genuine, example of that kind of step forward.").

${ }^{245}$ Gilbert, supra note 233.

${ }^{246}$ Delaware Governor Jack Markell, A New Kind of Corporation to Harness the Power of Private Enterprise for Public Benefit, HuFF. Post, (July 22, 2013), http://www.huffingtonpost.com/gov-jackmarkell/public-benefitcorporation_b_3635752.html ("Because of Delaware's leading role in U.S. corporate law, enactment of benefit corporation legislation in my state is critical for these businesses that seek access to venture capital, private equity, and public capital markets.").

${ }^{247}$ Alicia E. Plerhoples, Delaware Public Benefit Corporations 90 Days Out: Who's Opting In?, 14 U.C. DAvis Bus. L. J. 247, 253 (2014).

${ }^{248}$ E-mail from Richard J. Geisenberger, Chief Deputy Secretary of State to Tanner Wm. Polce, Delaware State Senate (forwarded to Meghan Poff, BSPA candidate of Indiana University Bloomington on Feb. 1st, 2016) (on file 
460 PBCs, thirty-four have since merged, been dissolved, or otherwise terminated, leaving a net of 426 PBCs as of August $2016 .{ }^{249}$ Seven companies submitted the necessary paperwork and converted to this corporate form on the first day of the law's coming into force. ${ }^{250}$ There were, in total, seventy-six PBCs incorporating in Delaware in 2013, 159 in 2014, and a record of 225 forming in $2015,{ }^{251}$ indicating a growing governance trend toward this corporate form in the state.

An industry analysis of PBCs that incorporated in Delaware within the first three months showed that the PBC statute did contribute to the state's economic growth, though not by attracting investment or creating jobs to the most recessive sectors as its proponents had hoped. Among all companies that converted to PBCs in Delaware within the first three months of the bill's enactment, thirty-one percent of them fell within the professional and technical services sector and the financial and insurance sector, ${ }^{252}$ which turned out to be the fastest-growing sectors in Delaware from 2013-14. ${ }^{253}$ Consumer retail products, technology, and education each constituted eleven percent of the cohort of the first fifty-five PBCs, which were also the fastest growing industries from 2013-14. ${ }^{254}$ On the other hand, none of those fifty-five PBCs were within the real estate, rental, and leasing sector, or the government sector, which were most recessive sectors from 2013 to 2014 in Delaware. ${ }^{255}$ Even though the economic impact from the Delaware PBC statute has not been as strong as legislators perhaps anticipated, the legislation had a positive impact on Delaware's economy. Since its introduction, PBCs have contributed several hundred-thousand dollars to Delaware's General Fund in the form of fees and franchise taxes. ${ }^{256}$

with author). A spreadsheet attached to the E-mail regarding all PBC that has been formed in Delaware that includes their "statement of specific public benefits" (on file with author).

${ }^{249} I d$.

${ }^{250}$ B Corporations See Growth During First Year in Del., News J. (Wilmington, Del.) (Nov. 24, 2013), available at 2013 WLNR 29611478.

${ }^{251}$ See Geisenberger, supra note 248.

${ }^{252}$ Plerhoples, supra note 201, at 262-64 (tracking PBCs incorporated within the first three months by industry and finding that seventeen of fifty-five provided professional services). 2013-2014,

${ }^{253}$ Table 2, Contribution to Percent Change in Real GDP by State,

http://www.bea.gov/newsreleases/regional/gdp_state/2015/xls/gsp0615.xlsx.

${ }^{254}$ See id.

${ }^{255}$ Table 2, Contribution to Percent Change in Real GDP by State, 2013-2014, available at http://www.bea.gov/newsreleases/regional/gdp_state/2015/xls/gsp0615.xlsx. ${ }^{256}$ Geisenberger, supra note 248. 
Delaware media's interest in its public-benefit corporation legislation mimics state legislative actions. From April 2013 to November 2013, there were a total of forty-eight news articles about "public benefit corporation" published in both local media sources like Wilmington News Journal, Delaware Business Blog, and News.Delaware.Gov., and national news sources like National Law Review, JD Supra, and The New York Times. However, there were only seven articles published in 2014. The number of media reports about PBCs increased to thirteen in 2015, as the 2015 Amendments to PBC statute was signed into law. From April 2013 to April 10, 2016, there were seventy-one media reports about PBC legislation in Delaware, ${ }^{257}$ as shown in Figure 3.

\section{Figure 3: NuMber of MEDiA ARTICles REFERENCING BeNEFIT CORPORATION IN DELAWARE, JANUARY 2013-JANUARY 2016 258}

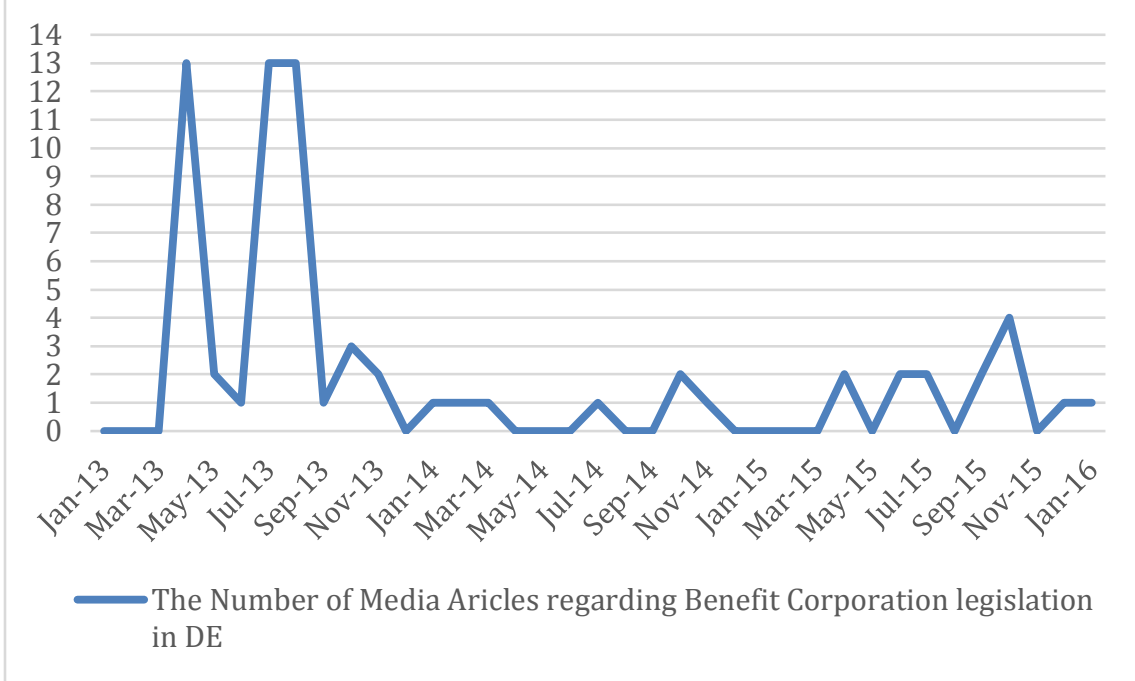

\section{Summary}

This final section of Part III summarizes the findings from the Connecticut and Delaware case studies in two tables. Table 1 compares the process by which the benefit corporation statutes were passed in the two states, including the number of attempts, amount of time required to pass the legislation, and the number of benefit corporations registered to date.

${ }^{257}$ Westlaw "Delaware news" database, search term "public benefit corporation." The results of research is on file with the authors.

258 This chart is based on Westlaw "Delaware News" database. The research covered media articles contains phrase "benefit corporation" from January 2013 to January 2016. 
Table 1: Procedural Benefit Corporation Statute SUMMARY MATRIX

\begin{tabular}{|c|c|c|c|c|c|}
\hline State & $\begin{array}{c}\text { Title of } \\
\text { Legislation }\end{array}$ & Stakeholders (for/against) & $\begin{array}{c}\text { \# of } \\
\text { Attempts to } \\
\text { Pass } \\
\text { Legislation }\end{array}$ & $\begin{array}{c}\# \text { of } \\
\text { Months to } \\
\text { Pass } \\
\text { Legislation }\end{array}$ & $\begin{array}{l}\text { \# of Benefit } \\
\text { Corporations } \\
\text { Registered }\end{array}$ \\
\hline Connecticut & $\begin{array}{c}\text { An Act } \\
\text { Concerning } \\
\text { Benefit } \\
\text { Corporations and } \\
\text { Encouraging } \\
\text { Social Enterprise; }\end{array}$ & $\begin{array}{c}\text { Supporters: } \\
\text { Gov. Dannel P. Malloy; } \\
\text { American Association of } \\
\text { Retired Persons (AARP); The } \\
\text { Tan200 International Holdings } \\
\text { Corporation; BI Cares; } \\
\text { Connecticut Technology } \\
\text { Council (CTC); Simply } \\
\text { Smiles; Department of } \\
\text { Economic and Community } \\
\text { Development (DECD); } \\
\text { Connecticut Innovations (CI); } \\
\text { CT Veterans Chamber of } \\
\text { Commerce; Secretary of the } \\
\text { State; CT News Junkie and the } \\
\text { Independent Media Network; } \\
\text { Connecticut Business \& } \\
\text { Industry Association; B Lab; } \\
\text { Connecticut Bar Association; } \\
\text { iMission Partners LLC; } \\
\text { Choice Business \& Personal } \\
\text { Coaching LLC; reSET; CT } \\
\text { Nonprofits; Connecticut } \\
\text { Conference of Independent } \\
\text { Colleges (CCIC); } \\
\text { The Walker Group; } \\
\text { GoodStreets; MHW LLC; A } \\
\text { Happy Life; Supriyo B. } \\
\text { Chatterjee } \\
\text { Opponents: } \\
\text { None }\end{array}$ & 3 & $\begin{array}{l}2.5 \text { (Feb. } 7 \\
- \text { Apr. 24) }\end{array}$ & $\begin{array}{c}39 \text { (Jan. 24, } \\
2016)\end{array}$ \\
\hline Delaware & $\begin{array}{l}\text { An Act to Amend } \\
\text { Title } 8 \text { of the } \\
\text { Delaware Code } \\
\text { Relating to the } \\
\text { General } \\
\text { Corporation Law; }\end{array}$ & $\begin{array}{c}\text { Supporters: } \\
\text { Governor Jack Markell; } \\
\text { Delaware State Bar } \\
\text { Association; Delaware Court } \\
\text { of Chancery; Secretary of } \\
\text { State; B-Lab; } \\
\frac{\text { Opponents: }}{\text { None }}\end{array}$ & 1 & $\begin{array}{l}2.0 \text { (Apr. } \\
18 \text { - June } \\
13)\end{array}$ & $\begin{array}{c}460 \text { (Feb. } 1, \\
2016)\end{array}$ \\
\hline
\end{tabular}

As is apparent from Table 1, there were many more active stakeholders supporting the benefit corporation statute in Connecticut than Delaware, though the Delaware experience required only a single attempt to pass and was influenced by debate outside of the legislative process. In addition, far more benefit corporations were registered over similar time periods in Delaware than in Connecticut. However, this may be largely explained by the special status of Delaware as a seat of U.S. corporate law governance as was discussed above.

The substance of the Connecticut and Delaware benefit corporation statutes is also similar with the important addendum that Delaware departs more significantly from the Model Benefit 
Corporation Legislation. ${ }^{259}$ This may be seen in the differing provisions regarding the legal preservation provision, naming requirement, and appraisal rights shown in Table 2.

\section{TABle 2: Substantive Benefit Corporation Statute SUMMARY MATRIX}

\begin{tabular}{|c|c|c|c|c|c|}
\hline State & $\begin{array}{c}\text { Title of } \\
\text { Legislation }\end{array}$ & $\begin{array}{l}\text { Voting requirement } \\
\text { for Conversion }\end{array}$ & $\begin{array}{c}\text { Legacy } \\
\text { preservation } \\
\text { provision }\end{array}$ & $\begin{array}{c}\text { Naming } \\
\text { requirement }\end{array}$ & $\begin{array}{l}\text { Appraisal } \\
\text { Rights }\end{array}$ \\
\hline Connecticut & $\begin{array}{c}\text { An Act } \\
\text { Concerning } \\
\text { Benefit } \\
\text { Corporations } \\
\text { and } \\
\text { Encouraging } \\
\text { Social } \\
\text { Enterprise }\end{array}$ & $\begin{array}{l}\text { "Any such } \\
\text { amendment... shall be } \\
\text { approved by a minimum } \\
\text { status vote (the vote of } \\
\text { shareholders of each } \\
\text { class or series entitled to } \\
\text { cast at least two-thirds } \\
\text { of the votes that } \\
\text { shareholders of the class } \\
\text { or series are entitled to } \\
\text { cast on the action)"260 }\end{array}$ & $\begin{array}{l}\text { Allowing the } \\
\text { owners of a } \\
\text { benefit } \\
\text { corporation to } \\
\text { enact an } \\
\text { optional } \\
\text { clause in their } \\
\text { articles of } \\
\text { incorporation } \\
\text { that will } \\
\text { ensure that } \\
\text { their benefit } \\
\text { corporation } \\
\text { remains a } \\
\text { social } \\
\text { enterprise in } \\
\text { perpetuity. }\end{array}$ & N/A & Yes. ${ }^{262}$ \\
\hline Delaware & $\begin{array}{c}\text { An Act to } \\
\text { Amend Title } 8 \\
\text { of the } \\
\text { Delaware } \\
\text { Code Relating } \\
\text { to the General } \\
\text { Corporation } \\
\text { Law; }\end{array}$ & $\begin{array}{c}\text { ". . the approval of } 2 / 3 \\
\text { of the outstanding stock } \\
\text { of the corporation } \\
\text { entitled to vote } \\
\text { thereon."263 } \\
\text { (It was Ninety percent } \\
\text { in S.B. 47, 147th Gen. } \\
\text { Assemb. (Del. 2013)) }\end{array}$ & N/A & $\begin{array}{c}\text { "[M]ay } \\
\text { contain the } \\
\text { words "public } \\
\text { benefit } \\
\text { corporation," } \\
\text { or the } \\
\text { abbreviation } \\
\text { "P.B.C.," or } \\
\text { the } \\
\text { designation } \\
\text { "PBC,"264 (It } \\
\text { was } \\
\text { mandatory in } \\
\text { S.B. 47, } \\
\text { 147th Gen. } \\
\text { Assemb. } \\
\text { (Del. 2013)) }\end{array}$ & $\begin{array}{l}\text { Yes. }^{265} \\
\text { (There was } \\
\text { no such } \\
\text { provision in } \\
\text { S.B. 47, } \\
\text { 147th Gen. } \\
\text { Assemb. } \\
\text { (Del. 2013)) }\end{array}$ \\
\hline
\end{tabular}

Thus, as the case studies in Part III demonstrate, our thesis that more buy in from more stakeholders and different governance levels is critical for enhancing legitimacy and, ultimately, the success of benefit corporations, seems to have some merit. The high degree of grass roots support for benefit corporation legislation in Delaware, for example, correlates with the relative success of that state's benefit corporation registration efforts, as shown in Table 1. This link, and what the broader literature on

259 See supra note 208 and accompanying text.

${ }^{260}$ See S.B. 23, supra note 158 , at $\$ 2, \S 5$.

${ }^{261} I d$. at $\$ \S 6-7$.

${ }^{262} I d$. at $\$ 16$.

${ }^{263}$ S.B. 75 , supra note 221 , at $\$ 363(\mathrm{c})$.

${ }^{264} I d$. at $\$ 362(\mathrm{c})$.

${ }^{265} I d$. at $\$ 363(\mathrm{~b})$. 
polycentric governance adds to the discussion, is discussed further in Part IV.

\section{ANALYZING THE RISE OF BENEFIT CORPORATIONS AND THEIR GLOBAL IMPACT THROUGH POLYCENTRIC GOVERNANCE}

Given the importance seen in bottom-up efforts to push for, enact, and otherwise take advantage of benefit corporation statutes, this final Part considers benefit corporations within the overarching context of the literature on polycentric governance introduced in Part I with a special emphasis on Professor Elinor Ostrom's Design Principles. We also globalize our discussion, unpacking what lessons may be gleaned for policymakers in other U.S. states as well as other nations as they debate the creation of similar enabling legislation.

\section{A. Applying the Ostrom Design Principles to Benefit Corporations}

As stated in Professor Elinor Ostrom's groundbreaking book Governing the Commons, Professor Ostrom created an informative framework of eight design principles for the management of CPRs. ${ }^{266}$ These principles include the importance of: (1) "clearly defined boundaries for the user pool ... and the resource domain"; 267 (2) "proportional equivalence between benefits and costs"; 268 (3) "collective choice arrangements" ensuring "that the resource users participate in setting . . rules"; 269 (4) "monitoring . . . by the appropriators or by their agents"; ${ }^{270}$ (5) "graduated sanctions" for rule violators, ${ }^{271}$ (6) "conflict-resolution mechanisms [that] are readily available, low cost, and legitimate"; 272 (7) "minimal recognition of rights to organize"; 273 and (8) "governance activities [being] ... organized in multiple layers of nested enterprises." 274 Not all of Professor Ostrom's design principles are applicable in either the context of benefit corporations given that they were designed primarily for managing small-scale common pool resources, such as forests and lakes. However, some do have salience, and are addressed in turn to

\footnotetext{
${ }^{266}$ See OSTROM, supra note 7, at 212.

${ }^{267}$ BUCK, supra note 8 , at 32 .

${ }^{268}$ See OSTROM, supra note 7, at 90.

${ }^{269}$ BUCK, supra note 8, at 32.

${ }^{270} \mathrm{Id}$.

${ }^{271} I d$.

${ }^{272} \mathrm{Id}$.

${ }^{273}$ Ostrom, supra note 22, at 118 tbl. 5.3.

${ }^{274} I d$.
} 
better inform a discussion of appropriate policy responses to promote the future of socially responsible corporate law.

\section{Defined Boundaries}

According to Professor Ostrom, "The boundary rules relate to who can enter, harvest, manage, and potentially exclude others' impacts. Participants then have more assurance about trustworthiness and cooperation of the others involved." 275 In the benefit corporation context, this relates to having defined rules in place through benefit corporation statutes to help foster socially responsible corporate decision-making. It also links to the benefit corporation statute drafting and ratification process itself in that this corporate form is designed to foster a broader attitude to stakeholder engagement beyond just shareholders. Thus, laws enabling firms to organize in such a way as to maximize their ability to positively impact the public benefit such as through more lax voting requirements have merit. This may be seen in the Delaware example by that state's decision to decrease the voting threshold for benefit corporation formation from ninety percent to two-thirds of voting shares.

\section{Proportionality}

This design principle underscores the need for equity in a system so that some of the "users [do not] get all the benefits and pay few of the costs . . ."276 In many ways, it speaks to the heart of why benefit corporations are being created in the first place; that is, to make corporate law more socially responsible and responsive to the needs of diverse stakeholders. Legislation enabling firms to undertake this wider vision of risk management are already helping to drive this change, as may be seen in particular by the more than 450 firms that have already taken advantage of Delaware's PBC law.

\section{Collective-Choice Arrangements and Minimal Recognition of Rights}

Professor Ostrom's third design principle states "that most of the individuals affected by a resource regime are authorized to participate in making and modifying the rules related to boundaries, assessment of costs." 277 This principle implies the importance of engaged and proactive rulemaking by technical communities, the private sector, and the international

\footnotetext{
275 Id. at 119.

${ }^{276}$ Ostrom, supra note 273, at 120.

${ }^{277}$ Id.
} 
community. ${ }^{278}$ The active contributions on the part of B-Lab and state bar associations, as well as the AARP and veterans' groups, belie the necessity of active participation across numerous stakeholders at work in the benefit corporation legislative campaign. This was in particular shown in Delaware given that the early efforts in that state were from the bottom-up, as opposed to Connecticut that enjoyed more early public-sector champions.

\section{Monitoring}

According to Professor Ostrom, trust can typically only do so much to mitigate rule-breaking behavior. ${ }^{279}$ Eventually, some level of monitoring becomes important. In self-organized communities, typically monitors are chosen among the members to ensure "the conformance of others to local rules." 280 This plays out in the benefit corporation context through third party certification schemes organized by B-Lab among other outlets.

\section{Graduated Sanctions and Dispute Resolution}

Other insights from Professor Ostrom's principles such as the need for graduated sanctions for rule violators and effective dispute resolution speak to the importance of addressing legal ambiguities and establishing norms of behavior. The former point underscores the significance of not "[1] etting an infraction pass unnoticed," 281 meaning that the cost of flouting is agreed upon. This principle is not as yet as well developed in the benefit corporation context, but will likely progress especially in the dispute resolution context as benefit corporation legislation now has made clear certain requirements - such as naming and appraisal - that can be vetted by courts of law. Indeed, the Delaware's Chief Justice Strine advocacy for this corporate form and its numerous benefits has already led to significant legal academy attention as to its relative merits and potential drawbacks. ${ }^{282}$

\section{Nested Enterprises}

${ }^{278}$ See George J. Siedel \& Helena Haapio, Law as a Source of Strategic Advantage: Using Proactive Law for Competitive Advantage, 47 AM. Bus. L.J. 641, 656-57 (2010) (discussing the origins of the proactive law movement, which may be considered "a future-oriented approach to law placing an emphasis on legal knowledge to be applied before things go wrong.").

${ }^{279}$ Ostrom, supra note 273, at 120.

${ }^{280} \mathrm{Id}$.

${ }^{281} I d$. at 121.

${ }^{282}$ See, e.g.. Strine, Do the Right Thing, supra note 16, at 244. 
As stated by Professor Ostrom, "When common-pool resources that are being managed by a group are part of a larger set of resource systems, an eighth design principle is usually present in robust systems. The nested enterprise principle states that governance activities are organized in multiple layers of related governance regimes." 283 Just as this multilevel system is imperative for environmental governance in large ecological systems with distinct local dynamics, ${ }^{284}$ so too is it essential for socially responsible corporate law. This is in particular seen in the relative success of the Connecticut and Delaware experience with drafting benefit corporation legislation as compared to other states such as Virginia, which was passed more easily but has not enjoyed as much success in terms of media coverage or the number of benefit corporations registered. ${ }^{285}$ Nor are the design principles the whole story; indeed, work is now underway to build on these design principles by creating a common vocabulary for CPR assessment through combining the Instituional Analysis and Design Framework with the Social-Ecological-Systems (SES) Framework, creating the IAD-SES Framew ork. ${ }^{286}$ Together, these governance frameworks combined with findings from the literature on institutional analysis can help define CPR-management best practices relevant not only to U.S. firms wishing to maximize their public benefit, but also to organizations around the world grappling with similar questions.

\section{B. Global Dimension}

Beyond U.S. policymakers, this governance research also has implications for how other nations are regulating to enhance socially responsible corporate law. Although jurisdictions ranging from Poland to Australia are debating the most appropriate mechanisms for regulating firms pursuing the public benefit, ${ }^{287}$ the focus here is on the European Union given that, in many ways, European corporate law enjoys the longest, and in many ways, most diverse, history with regards to socially responsible investing.

${ }^{283}$ Ostrom, supra note 273 , at 122.

${ }^{284} I d$.

${ }^{285}$ Virginia case study information was omitted due to space constraints but is on file with author.

${ }^{286}$ For more on this topic, see generally Scott J. Shackelford, On Climate Change and Cyber Attacks: Leveraging Polycentric Governance to Mitigate Global Collective Action Problems, 18 VAND. J. OF ENT. \& TECH. L. 653 (2016).

287 See, e.g., Developing model legislation for Australian B Corps, B CORP., http://bcorporation.com.au/benefitcorp_au (last visited Mar. 8, 2016); BENEFIT CORPORATIONS: A CASE STUDY OF THE US AND LESSONS FOR Australia, B LAB AUSTRALIA (2014), http://www.socialimpacthub.org/wpcontent/uploads/2015/01/2014-BLab-Report.pdf. 
As such, it is worth considering the ways in which European regulators and businesses have conceptualized socially responsible corporations to see what lessons may be learned from the U.S. experience with benefit corporations.

\section{Defining "Social Enterprise" Globally}

Concerns regarding short-term shareholder wealth maximization discussed in Part II are not confined to the United States; indeed, entrepreneurs ranging from Bill Gates to Richard Branson to Muhammad Yunus have voiced their frustration in this vein. ${ }^{288}$ The private sector is responding with more than $\$ 3$ trillion invested in socially responsible firms globally. ${ }^{289}$ Yet, despite this widespread interest, general agreement as to the definition of key terms, including "social entrepreneurship," is lacking in the relevant international academic literature, but generally combines some "elements of the social purpose, the market orientation, and financial-performance standards of business." 290 To take one example, the Canadian Centre for Social Entrepreneurship defines "social entrepreneurs" as "leaders in the field of social change and can be found in the private, public, and non-profit sectors," 291 whereas other authors have defined "social entrepreneurs" merely "as non-profit executives, who pay increasing attention to market forces." 292 As such, there is a lack of consensus on first principles, which is in turn is mirrored in the array of socially responsible corporate forms emerging across Europe.

\section{Unpacking European Socially Responsible Corporate Law}

Europe in many ways is considered to be "the birthplace of modern social enterprise." 293 Yet European corporate law is distinct from its U.S. cousin along a number of dimensions, including the former's emphasis on establishing institutional

${ }^{288}$ See Robert T. Esposito, The Social Enterprise Revolution in Corporate Law: A Primer on Emerging Corporate Entities in Europe and the United States and the Case for the Benefit Corporation, 4 WM. \& MARY BUS. L. REV. 639, 639 (2013).

${ }^{289}$ See, e.g., Alina Tugend, Picking Stocks That Don't Sin, N.Y. TIMES (Mar. 17, 2007), https://www.nytimes.com/2007/03/17/business/17shortcuts.html?pagewanted=p rint.

${ }^{290}$ See Galera Giulia \& Carlo Borzaga, Social Enterprise: An International Overview of its Conceptual Evolution and Legal Implementation, 5 SOCIAL ENT. J. 210, 212 (2009).

${ }^{291}$ Id. at 218.

292 Id.

${ }^{293}$ See Esposito, supra note 288, at 671. 
structures that are designed "to pursue a social good in a stable and continuous way through the production of goods or services of general-interest." 294 In other words, there is a strong collectivist undercurrent in European corporate law that is largely absent in U.S. law, enabling groups to come together to create organizations with "specific and well defined social" goals in mind that in turn boasts complementary institutional characteristics. ${ }^{295}$ However, despite the collectivist European mindset in corporate law, the way that many European nations - and indeed the European Union itself with the notable exception of the UK, as will be discussedhave approached the topic is narrower than in the United States, which has artificially limited the number and type of such firms. Given this narrower definition that preferences social goods, environmental causes are often sidestepped relative to the U.S. ${ }^{296}$

As within the U.S. context, in which social enterprises can take an array of forms including benefit corporations, European organizations boast a range of fluid choices when it comes to picking socially optimal corporate forms. ${ }^{297}$ Traditionally, most socially responsible organizations within Europe opted for either the cooperative or association models as most advantageous - both of which are inward-facing model designed to benefit the members than benefit corporations - with France and Belgium pioneering social enterprises that provided greater flexibility when it came to competing in the open marketplace. ${ }^{298}$ France began experimenting with a new corporate form - the Co-operative Society of the Common Interest (Société Coopérative d'Interet Collectif-SCIC - in 2001, which empowered local communities to establish cooperatives, gain access to public funds, and still pursue traditional business functions. ${ }^{299}$ The law also diversified the stakeholders within such organizations, which may have also slowed down the growth of SCICs. ${ }^{300}$ Belgium has been a pioneer in European socially responsible corporate law, such as may be seen by the rise of the "social purpose company (Société à Finalité Sociale) in $1995 .{ }^{301}$ Unlike in Italy, Portugal, or other European

${ }^{294} I d$

295 See id.

${ }^{296}$ Id. at 672.

297 See Giulia \& Borzaga, supra note 290, at 220.

298 See id.

${ }^{299} I d$. at 221.

${ }^{300} \mathrm{Id}$.

${ }^{301}$ Id. at 222; Esposito, supra note 288, at 673 (noting that "Belgium's legislation did not create a new corporate entity, but rather created a certification available to all types of business organizations. In order to obtain this certification, the organization must define a profit allocation policy and permit employee participation in the organization's governance structure through ownership of capital shares."). As Matthew Doeringer notes, in the eight years 
nations, in Belgium these firms can be used by any private firm with no reservations on the type of public purpose involved. ${ }^{302}$ However, these firms are only allowed to seek a "limited profit" and must "define the social good" that they are targeting. Italy allowed for the formation of social enterprises beginning in $1991,{ }^{303}$ which has since led to the formation of more than 7,000 Italian social enterprises employing some 250,000 workers, leading to its 2015 benefit corporation statute. ${ }^{304}$ Other nations followed Italy's success in this space, including Portugal, Spain, and Poland; however, many have continued to limit the activities of social enterprises. ${ }^{305}$

Today, modern European socially responsible corporate law may be "defined by different types of social cooperatives aimed at providing work integration services and personal services for the disadvantaged." 306 The most popular type of socially responsible business form remains social cooperatives, which are considered to be "the most widespread social enterprise entities in Europe" with nearly all the European nations having authored their own version of social cooperative entity legislation. ${ }^{307}$ The most popular version of these cooperatives is a Work Integration Social Enterprise (WISE) business form, whose goal it is "to help lowqualified unemployed people, who are at risk of permanent exclusion from the labour market." 308 Table 3 summarizes some of the predominant socially responsible corporate forms in Europe.

\section{TABLE 3: EUROPEAN SOCIAL ENTERPRISES DESIGNATIONS ${ }^{309}$}

following the creation of Belgium's scheme, "only 400 SFSs registered with the Belgian government." Id. at 674.

${ }^{302}$ Giulia \& Borzaga, supra note 290, at 222.

${ }^{303} \mathrm{Id}$.

${ }^{304}$ Id.

${ }^{305}$ For example, Portugal's 1998 social enterprise law was focused on the cause of giving "support to vulnerable groups (children, youth, disadvantaged persons, old persons), families and socially disadvantaged communities in view of their economic integration, as well as to Portuguese emigrants in difficulties; to establish support programs; and to promote both education and work integration of socially disadvantaged groups." Id. at 221 .

${ }^{306}$ Esposito, supra note 288, at 671.

${ }^{307} \mathrm{Id}$. at 672.

${ }^{308} I d$. (quoting Jacques Defourny \& Marthe Nyssens, Social Enterprise in Europe: Recent Trends and Developments, 4 SOC. ENTERPRISE J. 202, 207 (2008)).

${ }^{309}$ Id. at 12 . 


\begin{tabular}{|c|c|c|c|}
\hline Country & Legal forms used & Law/Year & Activities \\
\hline Italy & Social cooperative & $381 / 1991$ & $\begin{array}{l}\text { Social services } \\
\text { (a-type) } \\
\text { Work integration (b-type) }\end{array}$ \\
\hline Spain & $\begin{array}{l}\text { Social cooperative societies } \\
\text { Labour integration } \\
\text { cooperative societies }\end{array}$ & $\begin{array}{l}\text { National law } 27 / 1999 \text { and } \\
\text { regional laws in } 12 \\
\text { antonomous regions } \\
(1993-2003)\end{array}$ & $\begin{array}{l}\text { Assistance services in the } \\
\text { fields of health, edocation, } \\
\text { culnure or any activity of a } \\
\text { social nature } \\
\text { Work-integration }\end{array}$ \\
\hline Portagal & Social Solidarity cooperatives & $\begin{array}{l}\text { Co-operative code (Law } \\
1^{6} 51 / 96 \text { of } 7 \text { Seplember } \\
1996 \text { ) and Legislative } \\
\text { decree } n^{\circ} 7 / 98 \text { of } 15 \\
\text { January } 1998\end{array}$ & $\begin{array}{l}\text { Work-integration of } \\
\text { vulnerable groups }\end{array}$ \\
\hline France & $\begin{array}{l}\text { General-interest cooperative } \\
\text { societies }\end{array}$ & Law of 17 July 2001 & $\begin{array}{l}\text { Production or provision of } \\
\text { goods and services of } \\
\text { collective interest }\end{array}$ \\
\hline
\end{tabular}

An outlier in the European experience with developing socially responsible corporate law has been the UK, which has taken a broader view of "for-profit, mission-driven social enterprise" and "now enjoys the most robust social enterprise sector in Europe." 310 As such, the UK's experience in this sector is briefly discussed next before delving into the road ahead and applying lessons learned from the case studies in Part III toward advancing international socially responsible corporate law.

\section{Case Study: The UK's Community Interest Company Approach}

The UK is experimenting with an array of legislative approaches to furthering he cause of socially responsible corporate law, including the Community Interest Company (CIC) approach, ${ }^{311}$ which is "designed for enterprises that want to use their profits and assets for the public good[, particularly] to complement government services at the community level in areas such as childcare provision, social housing, community transport or leisure."312 In the UK, prior to the rise of CICs there was a frustration, according to Stephen Lloyd-one of the CICs chief architects - with English corporate law, particularly that it made it "quite complicated to embed social purposes in a legal form because there was not an off-the-shelf, simple-to-use legal entity ready for social enterprise unless you used the old-fashioned industrial and provident societies - the law for which has not been updated since 1965."313

${ }^{310}$ Esposito, supra note 288, at 674.

${ }^{311}$ See Giulia \& Borzaga, supra note 290, at 224.

${ }^{312} \mathrm{Id}$.

${ }^{313}$ Stephen Lloyd, Transcript: Creating the CIC, 35 VT. L. Rev. 31, 31-32 (2010). 
The result was the CIC, which was recognized as part of the 2004 Companies Act. ${ }^{314}$ These organizations are typically limited liability firms overseen by boards of directors and subject to checks and balances to ensure that they promote community interests. ${ }^{315}$ CICs in the UK are overseen by the CIC Regulator, and must register with the Companies House, a body similar in function to the Secretaries of State in the United States, to ensure that the activity in question is "for the benefit of the community." 316 Assets are also "locked" in CICs so as to further ensure their community benefit. ${ }^{317}$ Despite these strictures, CICs have proven to be incredibly popular within Britain; more than 6,400 had been registered as of 2012, making them the most successful socially responsible corporate form in Europe. ${ }^{318}$

Part of the reason for the success of the UK's socially responsible investment culture have been the incentives that the British government has put into place to spur the uptake of new corporate forms. These include: (1) the creation of an informative website, (2) the opening of "regional social enterprise development centers," (3) the selection of "thirty-five social enterprise ambassadors tasked with spreading information in local communities," (4) the "establishment of a $£ 10$ million fund for investment in social enterprise," (5) and the "creation of programs to develop better metrics for valuing the social benefits produced by social enterprise." 319 However, CICs are not without their critics, including those that focus on the restrictive dividend policies in this regime, and the lack of any tax breaks or benefits for these corporate forms. ${ }^{320}$ Table 4 highlights the CIC along with new socially responsible legal forms being tried across the EU.

TABLE 4: RECENT EUROPEAN SOCIAL ENTERPRISE LEGAL FRAMEWORKS ${ }^{321}$

${ }^{314}$ Companies (Audit, Investigations and Community Enterprise) Act, 2004, c. 27, § 26 (U.K.) [hereinafter Companies Act].

${ }^{315}$ Esposito, supra note 288, at 675.

${ }^{316}$ Id. at 676; The Community Interest Company Regulations, 2005, S.I. $2005 / 1788$, art. 2 , II 4 (U.K.).

${ }^{317}$ For more on "asset locks" in CICs, see Esposito, supra note 288, at 676.

${ }^{318}$ Id. at 676-77; Community Interest Companies Register, DEP'T FOR BUS. INNOVATION \& SKILLS, http://webarchive.nationalarchives.gov.uk/+/http://www.bis.gov.uk/cicregulator/ cic-register (last updated Apr. 4, 2012).

${ }^{319}$ posito, supra note 288 , at 676 .

${ }^{320} \mathrm{Id}$. at 677.

${ }^{321} I d$. at 16. 


\begin{tabular}{|c|c|c|c|c|c|}
\hline Coantry & $\begin{array}{l}\text { Legal formis } \\
\text { used }\end{array}$ & $\begin{array}{c}\text { Protit } \\
\text { distribution }\end{array}$ & Goveraske & $\begin{array}{c}\text { Eatrepueneuria } \\
\text { I model }\end{array}$ & Definition of wocial aim \\
\hline $\begin{array}{l}\text { Betgaum } \\
\text { Law of } 13 \\
\text { April } 1995\end{array}$ & 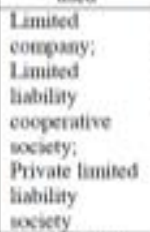 & $\begin{array}{l}\text { Redistribution } \\
\text { of profies in } \\
\text { possible, but } \\
\text { limited }\end{array}$ & $\begin{array}{l}\text { Participatory } \\
\text { aanere }\end{array}$ & & 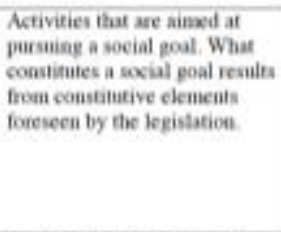 \\
\hline $\begin{array}{l}\text { thaly } \\
\text { Low a. } 118 \\
\text { of } 13 \text { Jwee } \\
2005\end{array}$ & $\begin{array}{l}\text { Associntioes: } \\
\text { Foumbtaons; } \\
\text { Co-operatives: } \\
\text { For profit } \\
\text { enterprises }\end{array}$ & $\begin{array}{l}\text { Duect and } \\
\text { indirest } \\
\text { distritutice of } \\
\text { peofis } \\
\text { percubited }\end{array}$ & $\begin{array}{l}\text { Panticipalosy } \\
\text { banue }\end{array}$ & Collective & 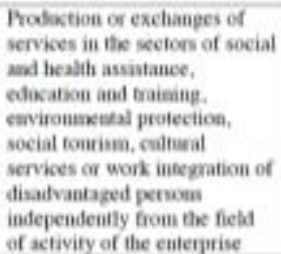 \\
\hline $\begin{array}{l}\text { Finland } \\
\text { Lw o: } \\
1351 / 2003\end{array}$ & $\begin{array}{l}\text { All entergmises } \\
\text { regardiess of } \\
\text { their legal } \\
\text { form and } \\
\text { ounenhiy } \\
\text { strostus }\end{array}$ & $\begin{array}{l}\text { Destnbestion of } \\
\text { feofits allowed } \\
\text { widh no } \\
\text { constraints }\end{array}$ & $\begin{array}{l}\text { Panticipatoey } \\
\text { governanee } \\
\text { not } \\
\text { envisaged }\end{array}$ & Not releyait & 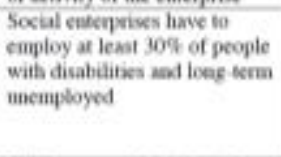 \\
\hline $\begin{array}{l}\text { United } \\
\text { Kingdom } \\
\text { Coumusaity } \\
\text { Interest } \\
\text { Company } \\
\text { regulatices } \\
\text { soos }\end{array}$ & $\begin{array}{l}\text { Euterprises } \\
\text { regulated by } \\
\text { Coupasies } \\
\text { Aet of } 1985\end{array}$ & $\begin{array}{l}\text { Partial } \\
\text { distributice of } \\
\text { profits allowed }\end{array}$ & $\begin{array}{l}\text { Participatery } \\
\text { aatuere }\end{array}$ & $\begin{array}{l}\text { Collective and } \\
\text { individual }\end{array}$ & $\begin{array}{l}\text { Wide range of activitiss that } \\
\text { comespond to die nceds of } \\
\text { comatasnitiss. Social definition } \\
\text { asseased by the Regulator }\end{array}$ \\
\hline $\begin{array}{l}\text { EMIES } \\
\text { Definition }\end{array}$ & $\begin{array}{l}\text { Ali legal form } \\
\text { adtaitted }\end{array}$ & $\begin{array}{l}\text { Partial } \\
\text { distritutice of } \\
\text { jeofies allowed }\end{array}$ & $\begin{array}{l}\text { Participatogy } \\
\text { natsere }\end{array}$ & Collestive & $\begin{array}{l}\text { Wide range of activities aimed } \\
\text { at pursuing an explicit secial } \\
\text { eoal }\end{array}$ \\
\hline
\end{tabular}

\section{Looking Ahead and Applying Lessons Learned}

In the wake of the 2008-09 global financial crisis, there has been a new wave of social enterprise legislation across Europe as seen in the UK case study. ${ }^{322}$ Looking ahead, the EU has adopted a "Europe 2020" strategy to help foster "smart, sustainable and inclusive growth" across the continent. ${ }^{323}$ One of the initiatives within the Europe 2020 Strategy is the need to boost social entrepreneurship, ${ }^{324}$ particularly social investment funds to help expand the nearly five million European jobs now supported by social cooperatives. ${ }^{325}$ Indeed, according to one 2009 study, nearly twenty-five percent of all European businesses fell under the heading of "social enterprise." 326 Beyond scaling up social investment funds across the EU, other proposals for expanding the sector have included mechanisms to enhance the visibility of socially responsible best practices such as a "public database of

${ }^{322}$ Esposito, supra note 288, at 671.

${ }^{323}$ Europe 2020: A Strategy for Smart, Sustainable and Inclusive

Growth, at 5, COM (2010) 2020 final (Mar. 3, 2010).

${ }^{324} I d$. at $14-15 ;$ Id . at 679 .

${ }^{325} \mathrm{Id}$. at 679 .

326 Siri TerJesen et AL., Global ENTREPRENEURShip MONITOR, 2009 REPORT ON SOCIAL ENTREPRENEURSHIP 20, http://www.gemconsortium.org/docs/download/2519. 
labels and certifications" that socially responsible firms could contribute to and share. ${ }^{327}$

Yet "[d]espite this conclusion, the suggestions of the European Commission continue to reflect a narrow view of social enterprises as strictly charitable organizations." ${ }^{328}$ Myriad areas for improvement remain, including geographically. Eastern Europe, for example, has lagged behind Western Europe due in part to "cultural opposition and skepticism to cooperative forms" and "the absence of legal frameworks to regulate cooperatives." 329 However, learning goes both ways. The U.S. could absorb lessons from the UK's incentive structures, especially combined with the tax breaks missing in the UK's CIC scheme. Similarly, other European nations could learn from the comparative case studies detailed in Part III, as well as Italy's recent experience in passing benefit corporation legislation, different from social enterprise law, "seen as a new revolutionary step forward, within a context traditionally static and sometimes obsolete. ${ }^{330}$ In particular, grass roots support is vital, especially efforts aimed at influencing influential jurists and policymakers. This was true in the case of Delaware, for example, in that Chief Justice Strine's advocacy was instrumental in the eventual passage (and subsequent amendment) of the Delaware PBC statute. Regarding the substance of these laws, as Delaware and to a lesser extent Connecticut makes clear, states and other jurisdictions can and should apply their own unique perspective and variations to the Model Law; experimentation and evolution are part and parcel of polycentric governance. Eventually, as more states and nations craft versions of these laws, businesses will vote by seeking out those jurisdictions that are best suited to their corporate visions. This is already happening to an extent in Delaware given the more than 450 firms that have already sought out registration in that jurisdiction. Such an approach could also aid in norm building, with states and firms acting as norm entrepeneurs that could eventually cause a "norm cascade" toward CPR governance. 331

\section{CONCLUSION}

${ }^{327}$ Esposito, supra note 288, at 680.

${ }^{328} \mathrm{Id}$. at 681 .

${ }^{329} \mathrm{Id}$. at 673 .

${ }^{330}$ See Alissa Pelatan \& Roberto Randazzo, Eur. Soc. L. Assoc., at 6, The First European Benefit Corporation: Blurring the Lines Between 'Social' and 'Business,', www.bwbllp.com/file/benefit-corporation-article-june-16-pdf (last visited, November 17, 2016).

${ }^{331}$ See Martha Finnemore \& Kathryn Sikkink, International Norm Dynamics and Political Change, 52 INT'L ORG. 887, 895-98 (1998). 
This Article has assessed the rise of benefit corporations through the lens of CPR theory, and leveraged the literature on polycentric governance to help explain the relative successes of jurisdictions that have been experimenting with versions of this novel corporate form. As has been shown, we may well be at a tipping point of benefit corporation acceptance with not only influential Delaware and a supermajority of U.S. states now allowing firms to organize for the public benefit, but an increasing number of nations in Europe and elsewhere recognizing the powerful potential of this type of organization. The trend could lead to a pivot away from the private good conception of the firm and back towards its CPR Roman law origins. Indeed, "the benefit corporation is the most promising entity for social entrepreneurs," 332 but whether it will fulfill the promise is yet to be seen. Answering this question will require both managers and policymakers to internalize the governance best practices emerging from jurisdictions like Connecticut and Delaware, and to continue experimenting from the bottom-up for the public benefit.

${ }^{332}$ Esposito, supra note 288, at 714 (also stating that the benefit must overcome the LLC form as a vehicle). 